\title{
Use of settlement patterns and geochemical tagging to test population connectivity of eastern oysters Crassostrea virginica
}

\author{
Haley N. Gancel ${ }^{1,2, *}$, Ruth H. Carmichael ${ }^{1,2}$, Jiabi Du ${ }^{3}$, Kyeong Park ${ }^{4}$ \\ ${ }^{1}$ University of South Alabama, Mobile, AL 36688, USA \\ ${ }^{2}$ Dauphin Island Sea Lab, Dauphin Island, AL 36528, USA \\ ${ }^{3}$ Woods Hole Oceanographic Institution, Woods Hole, MA 02543, USA \\ ${ }^{4}$ Texas A\&M University at Galveston, Galveston, TX 77554, USA
}

\begin{abstract}
Freshwater-dominated estuaries experience large fluctuations in their physical and chemical environments which may influence larval dispersal, settlement, and connectivity of populations with pelagic larval stages. We used settlement patterns and natural tagging along with numerical hydrodynamic model results to assess settlement and connectivity among oysters across the freshwater-dominated Mobile Bay-eastern Mississippi Sound (MB-EMS) system. Specifically, we (1) tested how freshwater inputs and associated environmental attributes influenced settlement patterns during high and low discharge conditions in 2014 and 2016, respectively, and (2) analyzed trace element (TE) ratios incorporated into multiple shell types (larval and settled shell of spat and adult shells) to determine if shells collected in situ incorporate temporally stable site-specific signatures. We also assessed if TE ratios compared between adult (TE natal signature proxy) and larval shells could infer connectivity. Larval settlement was $4 \times$ higher during low discharge than during high discharge when oyster larvae only settled in higher salinity regions (EMS). Spat and adult shells incorporated site-specific TE ratios that varied from weeks to months. Connectivity results (May-June 2016 only) suggest that EMS is an important larval source to EMS and lower MB. While we were able to infer probable connectivity patterns using adult and larval shells, more study is needed to assess the utility of adult shells as proxies for natallocation TE signatures. Results provide a baseline for measuring future larval connectivity and adult distribution changes in the MB-EMS system. Biological and geochemical data demonstrate the potential to identify environmental attributes that spatiotemporally mediate settlement and connectivity in dynamic systems.
\end{abstract}

KEY WORDS: Larval transport · Larval settlement · LA-ICP-MS · Trace elements · Mobile Bay

\section{INTRODUCTION}

Many marine species have pelagic larval stages, and knowledge of larval dispersal and subsequent population connectivity is imperative to better understand population dynamics and manage populations (Thorrold et al. 2007). Larval dispersal and transport are difficult to quantify due to (1) uncertainty in lar-

*Corresponding author: haleygancel@gmail.com val sources and (2) difficulty of tracking microscopic larval movements in situ due to advection and high larval mortality (Levin 2006). Many species, including bivalves, also inhabit dynamic habitats often dominated by freshwater inputs (Pollack et al. 2011), which can modify larval transport and delivery of new recruits for settlement (Dong et al. 2012, Kim et al. 2013). Freshwater discharge, along with other

(C) The authors 2021. Open Access under Creative Commons by Attribution Licence. Use, distribution and reproduction are unrestricted. Authors and original publication must be credited. 
environmental factors such as winds, tides, and surface heat exchange, alters the chemical and physical environment (e.g. salinity, water temperature, and circulation patterns) that mediates reproduction, survival, growth, distribution, and settlement processes, which ultimately mediate connectivity (Wilber 1992, Kim et al. 2010, 2013). While it is relatively well-established that freshwater inputs affect the distribution and abundance of bivalves, with lower flows into high freshwater input systems resulting in more abundant adult bivalve populations and vice versa (Wilber 1992, Soniat et al. 2012), specifically how changes in freshwater discharge influence dispersal of larvae, settlement of recruits, and ultimately population connectivity has been less studied.

Geochemical tracers have been used as natural tags to indirectly track larvae, determine larval sources, define transport, and infer population connectivity (defined as where larvae originate from; Levin 2006) (Thorrold et al. 2002, Becker et al. 2005, Bradbury et al. 2011). Geochemical tracers such as trace elements (TEs) are incorporated into larval shells from the natal environment and retained throughout early development and settlement (Levin et al. 1993, Anastasia et al. 1998, DiBacco \& Levin 2000). If the ratio of these elements is location-specific, then larval origins can be identified by comparing larvae of unknown origin to natal reference signatures. Reference TE signatures need to be spatially distinct, encompass the potential dispersal distance (Miller et al. 2013a), and have low temporal variation during the pelagic period (Campana et al. 2000). Typically, natal reference signatures are determined using larval outplant studies, where hatchery-reared larvae are transplanted to larval homes at specific locations to measure TE ratio incorporation (Becker et al. 2007, Carson et al. 2010, Kroll et al. 2018). Outplant methods can be costly and timely to do, and thus, identifying proxies, such as juvenile or adult shells collected in situ to represent natal reference signatures, can be potentially useful (Sorte et al. 2013). Difficulties arise when using different shell types to classify larval origins. For example, mineralogical differences between adult and larval shell are present; adult bivalves are sedentary and can integrate TE signatures over longer time periods (i.e. weeks to years) than larvae, reflecting TE ratios of multiple larval cohorts or time periods where larvae were not present in the water column. Therefore, site-specific TE ratios in adult bivalve shell can potentially serve as a time-integrated proxy for natalsite reference TE signatures, but more study is warranted prior to the use of adult shells.
To determine the utility of geochemical tracers to track larval origins and movements within a system, the spatial and temporal variation of site-specific TE ratios needs to be defined. Elemental spatiotemporal variability is determined by differences in environmental (physical and chemical) and biological factors (Lorens \& Bender 1980, Vander Putten et al. 2000). Estuaries are ideal areas to study variation in TE ratios because they have high spatiotemporal environmental variability due to different geomorphologies, pollution sources, and freshwater inputs (Swearer et al. 2003, Thorrold et al. 2007). Previous estuarinebased studies have found spatial variation in TE ratios in bivalve shells across 1-10s of km (Norrie et al. 2016) and temporal variation on a scale of weeks to months in bivalve shells (Becker et al. 2005) and years in gastropod shells (Zacherl 2005). These findings suggest that spatiotemporal variation within estuaries should be adequate to distinguish larvae among natal sites using TE ratios. The ability to define spatial and temporal variation in TE ratios is of particular concern in freshwater-dominated systems where large-scale mixing may affect larval dispersal processes and reduce the spatial distinction of TE ratios among sites through time.

Oysters are commercially, ecologically, and biogeochemically important, particularly in the north-central Gulf of Mexico (nGoM), which is home to a few of the remaining commercially harvestable oyster populations worldwide (Beck et al. 2011). Eastern oysters are a spawning species that produce planktonic larvae lasting $\sim 2-3$ wk depending on environmental conditions (Medcof 1939). In the nGoM, eastern oysters are capable of spawning multiple larval cohorts throughout the year, typically between April and October (Ingle 1951, Butler 1965, Hayes \& Menzel 1981, Kim et al. 2010). Spawning is temperaturedependent and is induced when temperatures reach $>25^{\circ} \mathrm{C}$ or following a rapid increase or decrease in temperature (Hayes \& Menzel 1981, Saoud et al. 2000). Timing of spawning can influence connectivity because it regulates if gametes are released into optimal conditions for larval development and survival, which ultimately determines the larval pool for connectivity (Prytherch 1929). Larvae can disperse 0.1-100s of km (North et al. 2008, Haase et al. 2012, Puckett \& Eggleston 2016), during which a larval aragonite shell develops (Stenzel 1963, 1964). Freshwater discharge can influence connectivity by affecting the circulation pattern as well as the growth and survival of early life stages, which are salinitydependent, with optimum salinities for larval development and spat settlement between 7.5-22.5 and 
10-30, respectively (Calabrese \& Davis 1970, Chatry et al. 1983). Following the pelagic larval period, oysters settle under suitable conditions and remain in the settlement location throughout juvenile and adult life stages, incorporating TE ratios of settlement locations into a calcite shell (Stenzel 1963, 1964) representing long-term temporal scales. Thus, oysters are promising model organisms to understand how changes in freshwater discharge and associated environmental attributes mediate larval settlement and connectivity on different spatial and temporal scales.

To determine how changes in freshwater discharge influence oyster populations, we conducted a 2 part study to define larval oyster settlement patterns and connectivity using geochemical tags. We used the Mobile Bay-eastern Mississippi Sound (MB-EMS) system, a nGoM estuarine system with the $6^{\text {th }}$ largest freshwater drainage basin in the USA (Isphording \& Flowers 1987), as a model system. Previous studies have found oyster settlement to be highest in the southwest side of MB-EMS, following an increasing salinity gradient from northern to southern $\mathrm{MB}$ and westward into EMS, with negligible settlement in the middle, east, and upper portion of MB (Hoese et al. 1972, Lee 1979, Saoud et al. 2000, Kim et al. 2010). In the first part of this study, oyster spat settlement data were collected from areas of known oyster settlement in 2 different years with low and high discharge conditions to examine how the flow patterns and associated environmental attributes (salinity and temperature) determined by freshwater discharge, winds, and tides affect settlement of eastern oysters in the MB-EMS system. In the second part of the study, we (1) used newly settled oysters collected in the first part of the study and adult oysters to determine if larval, settled, and adult shells have sitespecific TE ratios and (2) conducted an exploratory analysis to assess connectivity using adult shells as natal reference TE signatures, comparing the larval component of shell from newly settled spat to adult shells to estimate larval origins. Because connectivity studies using TE ratios have not been conducted in freshwater-dominated systems, we verified our predictive methods by testing if (1) larval and post-settlement components of spat shell were sufficiently different to distinguish between natal origins and settlement locations, (2) larval, settled, and adult shells differed among sites to determine spatial distinctions due to variability in the physiochemical environment, and (3) TE ratios in larval, settled, and adult shells varied temporally on seasonal or annual scales. These data may have important implications for understanding how the spatial extent of oyster populations shift under changing discharge regimes in freshwater-dominated systems.

\section{MATERIALS AND METHODS}

\subsection{Settlement sampling}

\subsubsection{Sampling scheme}

To determine spat settlement patterns, settlement plates were deployed at settlement sites (Table S1 in the Supplement at www.int-res.com/articles/suppl/ m673p085_supp.pdf, Fig. 1) in the freshwater-dominated MB-EMS system throughout a region of historically known oyster habitat (Hoese et al. 1972, Lee 1979, Saoud et al. 2000), with sites EMS1-3 located

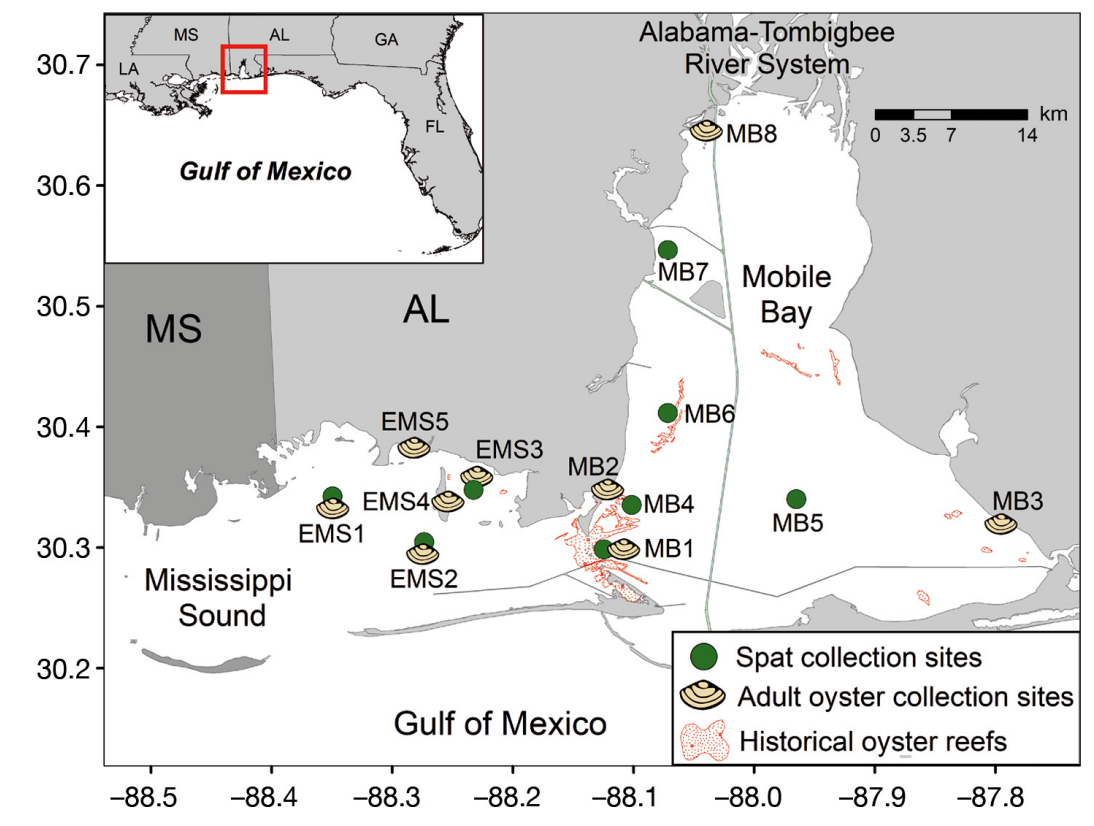

Fig. 1. Sampling locations included in the Mobile Bay-eastern Mississippi Sound system, including spat settlement plate and adult oyster collection sites. Stippled areas indicate known historical oyster reef locations (data from May 1971, Tatum et al. 1995, Alabama Department of Conservation and Natural Resources 2001) 
west to east in EMS and MB1, MB4-7 located south to north along a salinity gradient in MB. In 2016, 3 new settlement plate sites were added to include a natural reef site (EMS3) and historically productive oyster areas that have been unproductive in recent years (MB5 and MB7) (Stout et al. 1998). Plates were changed bimonthly from May to mid-September of 2014 and 2016.

\subsubsection{Settlement plate moorings}

Settlement plate moorings were attached to existing pilings, below the water surface to reduce potential vandalism. Moorings consisted of an $18.9 \mathrm{l}$ bucket with a steel pole $(25.4 \mathrm{~mm} \times 2.1 \mathrm{~m})$ cemented in the center with $18 \mathrm{~kg}$ of concrete, ratchet strapped to a piling. A PVC sheath holding 4 settlement plates was bolted in place $1 \mathrm{~m}$ above the bottom and accessible via snorkeling to allow easy access to plates without removing the mooring. Settlement plates $(17 \times 17 \mathrm{~cm})$ made of HardieBacker ${ }^{\circledR}$ Cement Board were deployed at a $45^{\circ}$ angle (Carleton \& Sammarco 1987, Dayton et al. 1989). Plates were pre-soaked in $0.7 \mu \mathrm{m}$ filtered seawater for $\sim 24 \mathrm{~h}$ to promote biofilm development in situ to increase settlement (Quayle \& Newkirk 1989, Tamburri et al. 2008). Prefiltering of seawater was done to remove organisms that could potentially affect settlement. To reduce predation while allowing adequate water flow, a half-caging method was used by placing $3.5 \mathrm{~mm}$ plastic mesh with 2 sides open with the top and bottom closed (Kim et al. 2010).

\subsubsection{Spat abundance}

Two settlement plates were analyzed per site; only the inner $16 \times 16 \mathrm{~cm}$ of the plate was analyzed (outer $1 \mathrm{~cm}$ excluded) to eliminate handling effects. Spat on settlement plates were examined with a Fisher Stereomaster zoom dissecting microscope (10-60× magnification). All spat were counted and distinguished as live (non-gaping and/or tissue present) or dead (spat scars or gaping oysters with no visible tissue).

\subsubsection{Environmental attributes}

To determine freshwater discharge, daily discharge data in 2014 and 2016 were downloaded from the US Geological Survey gauging stations 02428400 (Alabama River at Claiborne near Monroe) and 02469761
(Tombigbee River at Coffeeville); their sum was used as the total discharge into the MB-EMS system (Park et al. 2007). To determine environmental attributes at the time of sampling, temperature, salinity, and dissolved oxygen were measured at the depth of plates when changing plates bimonthly using a YSI pro 2030 handheld data sonde. To determine wind (direction and velocity) and water temperature, hourly data were downloaded from the Dauphin Island station DPIA1 (NOAA Tides and Currents). A wellvalidated 3-dimensional hydrodynamic model was used to simulate salinity at finer spatial and temporal resolution throughout the study area in 2014 and 2016. Detailed information of the model configuration and its application and validation can be found in Kim \& Park (2012) and Park et al. (2014).

\subsubsection{Settlement sampling statistical analyses}

To determine spatial variability in spat settlement, regression analysis was used to compare average numbers of spat settled to distance from freshwater input (i.e. head of Mobile Bay), to compare to previous studies done in the MB-EMS system. To compare settlement patterns found in this study to those from previous studies conducted in the MB-EMS system, literature data were collected from Hoese et al. (1972), Lee (1979), Saoud et al. (2000), and Kim et al. (2010), and their average settlement trends versus distance from freshwater input were compared to the results from this study. Data collected from Lee (1979) and Saoud et al. (2000) were not included in regression analyses due to having too few sites where spat settlement was measured. To determine spatial and temporal variability in spat settlement, general linear models (GLMs) were used with settlement site and week as factors. Negative binomial GLMs with log-links were run for 2014 spat settlement. To account for over-dispersed count data with zero inflation, 2016 spat settlement data were analyzed using a zero-altered negative binomial GLM with a log-link using the 'pscl' package in R (Jackman 2008).

To determine if discharge differed between years, a generalized additive model was run with a reduced maximum likelihood smoothing function using the 'mgcv' package in R (Wood 2012). To determine spatial and temporal variability in salinity and temperature, GLMs were run with settlement site and week as factors for sites and time periods that had appreciable settlement. For comparisons between years, GLMs with year, week, and settlement site as factors 
were run with salinity data for the same sites and time periods, and a $t$-test was performed for temperature comparisons. Because environmental variables measured at the time of plate collection represented a single time point that is not necessarily representative of conditions in the MB-EMS system during settlement in the days prior to collection, settlement data were not directly compared to environmental data. Rather, temperature and salinity patterns throughout the settlement season were analyzed, and time points at the beginning of consistent settlement were considered 'settlement events.' To determine environmental conditions potentially indicative of spawning or more suitable conditions for settlement, temperature and salinity changes 2 and 4 wk prior to the settlement event were assessed. These times were chosen based on an average $2-3 \mathrm{wk}$ pelagic larval duration where spawning and subsequent settlement could potentially be explained by environmental conditions during these time periods. For example, previous studies have indicated that settlement events commence about $3 \mathrm{wk}$ after a decline in temperature triggers spawning (Saoud et al. 2000). Two weeks prior to the settlement events were termed 'spawning events' and $4 \mathrm{wk}$ before were termed 'prior to spawning'.

Data were statistically modeled independently for 2014 and 2016 due to large differences in settlement between years and the addition of settlement plate sites in 2016. Due to overfitting of models, settlement sites and sampling periods with few $(\mathrm{n} \leq 3)$ spat settled were removed from models, such that data from MB4 and MB6 were removed from 2014 temporal settlement models, data from MB5 were removed from 2016 spatial and temporal settlement models, and data from MB7 were removed from 2016 temporal settlement models. For comparison between years, spatial and temporal settlement models were run from mid-May through mid-August to cover periods of common spat settlement and data acquisition.

All models were checked for the assumptions of linearity, normality, and heteroscedasticity of residuals. If assumptions were not met, appropriate model relationships, i.e. polynomial relationships, were used or data were log transformed. GLMs were re-run without significant factors and/or interactions in cases where factors and/or interactions were not significant. Final models were chosen using partial likelihood ratio tests. Week as a unit of time was used as a continuous variable in all models. An $\alpha$ of 0.05 was used for all tests, and error is presented as \pm SE. GLMs and the negative binomial GLM were run using the MASS package in R (Venables \& Ripley
2002). All analyses were conducted in RStudio v.1.1.453 and R v.3.5.0 (R Core Team 2017).

\subsection{TE analysis}

\subsubsection{Shell collection}

Spat shells $(1.3 \pm 0.1 \mathrm{~mm})$ collected from 2016 settlement plates were used for TE analysis. Spat from 2014 could not be used due to low and inconsistent spat settlement and shell fragility. Spat shells were collected at all settlement plate sites in Fig. 1 except MB7 due to inconsistent plate recovery. Adult oysters (5.0 \pm $0.6 \mathrm{~cm}$ ) were collected from The Nature Conservancy (TNC) Mobile Bay Restoration Project intertidal oyster reefs (sites EMS4, EMS5, MB2, and MB3) and opportunistically during field sampling from subtidal settlement plate sites (shell symbols in Fig. 1). Sample size $(n=3-5)$ at each site was limited by the number of available adult oysters, which are largely only present in southeastern Mobile Bay (indicated by red historical area in Fig. 1). Only adult oysters collected after September 2016, which were in the water for the duration of spat settlement sampling, were used for analysis to ensure that the time period of TE ratio acquisition overlapped between adult and spat shell.

\subsubsection{Shell preparation}

Spat shells were collected off settlement plates using a tungsten probe. To remove excess organic matter (i.e. mud and bryozoans), spat shells underwent 3 cycles of rinsing with ultrapure water and drying at $60^{\circ} \mathrm{C}$. Additional chemical treatments were not used to avoid altering the elemental composition of biogenic carbonate (Krause-Nehring et al. 2011) or degrading the fragile larval shells (Kroll et al. 2016). Adult oyster shells were radially sectioned (hinge to outer edge) using a Buehler Isomet ${ }^{\circledR} 1000$ Precision Saw using Isomet ${ }^{\mathrm{TM}}$ Diamond Wafering Blades (152.4 $\times 5.1 \times 12.7 \mathrm{~mm}$ ) to create a $2 \mathrm{~mm}$ thick section. For analysis, all shells (whole spat and adult sections) were mounted to slides using Scotch ${ }^{\mathrm{TM}}$ double-sided tape.

2.2.3. Laser ablation inductively coupled plasma mass spectrometry

Shells were ablated with an Nd: YAG NWR213 (Electro Scientific Industries) laser ablation system 
coupled with Agilent Technologies 7700x inductively coupled plasma mass spectrometry (ICPMS). Spat were ablated across the whole shell (umbo to outer edge; Fig. 2) with a $10 \mu \mathrm{m}$ spot size, scan speed of $10 \mu \mathrm{m} \mathrm{s}^{-1}, 25 \%$ intensity, and $10 \mathrm{~Hz}$ following pre-ablation at $20 \mu \mathrm{m}$ spot size, $50 \mu \mathrm{m} \mathrm{s}^{-1}$ scan speed, and $20 \%$ intensity. Laser intensities and scan speeds were chosen to ensure that the laser did not burn through the entire depth of spat shell, and all spat were checked under the microscope post-ablation. Adult shells were ablated on a transect from inner to outer surface (Fig. 2), perpendicular to internal lines of growth at a $25 \mu \mathrm{m}$ spot size, scan speed of $15 \mu \mathrm{m}$ $\mathrm{s}^{-1}, 45 \%$ intensity, and $10 \mathrm{~Hz}$ following pre-ablation at $40 \mu \mathrm{m}$ spot size, $50 \mu \mathrm{m} \mathrm{s}^{-1}$ scan speed, and $40 \%$ intensity. Three transects were run per shell, with a laser warm-up and washout delay of $30 \mathrm{~s}$ between transects. NIST 612 glass (National Institute of Standards and Technology) and MACS-3 calcium carbonate (US Geological Survey) reference standards (2 transects with identical parameters to shells) were run every hour and at the beginning and end of sampling.

Shells were sampled for ${ }^{24} \mathrm{Mg},{ }^{88} \mathrm{Sr},{ }^{137} \mathrm{Ba},{ }^{208} \mathrm{~Pb}$, ${ }^{57} \mathrm{Fe},{ }^{111} \mathrm{Cd},{ }^{63} \mathrm{Cu},{ }^{55} \mathrm{Mn},{ }^{66} \mathrm{Zn},{ }^{75} \mathrm{As},{ }^{60} \mathrm{Ni},{ }^{51} \mathrm{~V},{ }^{52} \mathrm{Cr}$, and ${ }^{59} \mathrm{Co}$ with ${ }^{43} \mathrm{Ca}$ as the internal standard. $\mathrm{Cd}$ and $\mathrm{As}$ were not detected in spat shells, while $\mathrm{Cd}$, As, and V were not detected in adult shells. Elements were chosen based on previous geochemical tracking studies conducted in estuarine environments (Becker et al. 2005, Kroll et al. 2018). Data reduction and limits of detection were calculated in Iolite software (version 3.63) using MACS-3 as the reference material and Trace_Elements as the data reduction scheme. Elements are reported as metal (Me):Ca in mmol $\mathrm{mol}^{-1}$. Spat transects $(\sim 1300 \mu \mathrm{m})$ were averaged along the first $150 \mu \mathrm{m}$ from the umbo and the last $150 \mu \mathrm{m}$ near the shell margin, representing larval and settled shell, respectively. Concentrations in adult shells were averaged for the whole transect (multi-year average) and $300 \mu \mathrm{m}$ of most recent growth (approximately a single year). Distance stratification along the shell was based on known growth relationships for adult and larval oysters in the region (Gallager et al. 1986, Kirby et al. 1998, Rikard \& Walton 2010).

\subsubsection{TE statistical analyses}

To determine if spawning and settlement sites had different elemental signatures, TE ratios of the

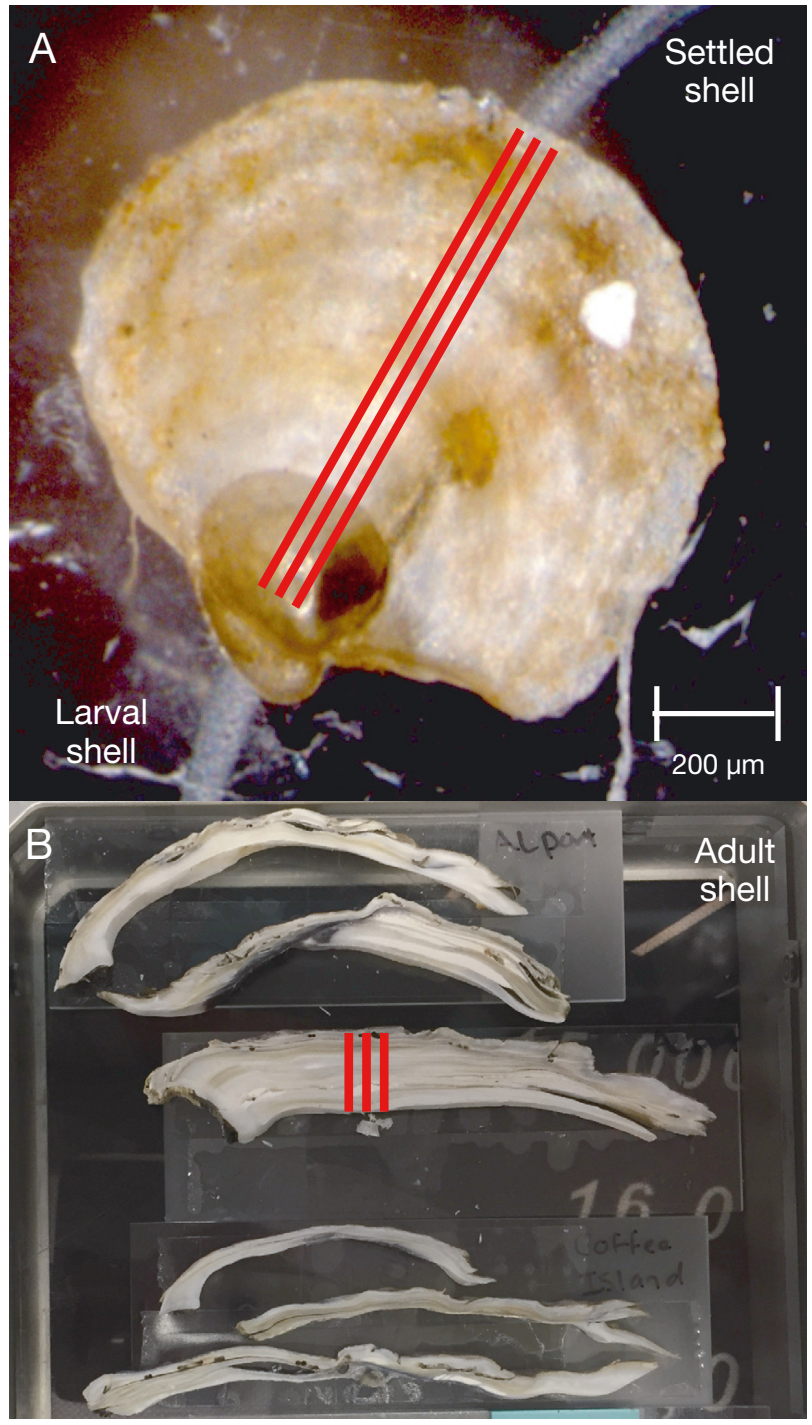

Fig. 2. Transect lines (red) run for trace element analyses on (A) spat and (B) adult shells. Spat shell transect lines were run from umbo (larval shell) to outer edge (settled shell). Adult shell transects were run perpendicular to growth lines from inner to outer surface. Three transect lines were run for each shell

larval versus settled shell were directly compared using 2-way MANOVAs (multi-elemental comparisons; Pillai's trace test statistic) with site and shell type as factors, followed by univariate ANOVAs (individual elemental comparisons). To determine if larval (i.e. natal site signature), settled (i.e. settlement location signature), and adult shells had sitespecific TE signatures, linear discriminant analyses (LDAs) were run for larval, settled, and adult shells separately.

To determine if the elemental composition in larval and settled shell grown during the study was similar 
within the spawning season, separate LDAs were run for larval and settled shells sampled during 3 spat collection time periods (May-June, July-August, and late-August-September 2016) and compared to determine variability in site separation. To determine if the elemental composition in adult shell grown during the study (most recent $300 \mu \mathrm{m}$ ) was similar to all previous years of shell growth, separate LDAs were run for the recent shell (single year) and whole shell (multiple years) and compared to determine variability in site separation.

To determine if adult shells could be used as a proxy of natal location TE signatures and provide probable connectivity patterns in the MB-EMS system, we determined larval origins by classifying larval shells of settled spat to site-specific TE ratios in the inner margin of adult shell. To predict larval origins, larvae were classified to sites using the most recent adult shell TE ratio LDAs that were run with (1) TE ratios chosen from larval shell LDA results (except V because it was not present in adult shell) and (2) without the northernmost MB site (MB8) from where larvae were unlikely to originate and could confound results (Gomes et al. 2016). Larval predictions were also attempted with whole-shell TE ratios, but differences among sites were greater for the recent shell LDA, and thus the whole-shell LDA was not used. As a validation for connectivity results and to ensure that differences between aragonite and calcite shell did not influence results, we re-ran larval predication analyses without the major $2^{+}$cations $(\mathrm{Mg}, \mathrm{Sr}$, and $\mathrm{Ba}$ ) that are readily substituted for $\mathrm{Ca}$ in the shell, and connectivity results were largely similar between the 2 results.

For all statistical tests, TE ratios were Box-Cox transformed. Multivariate outliers were identified by plotting robust squared Mahalanobis distances of the residuals against the corresponding quantiles $(Q-Q$ plot) of chi-squared distribution. Multivariate normality was tested using a multivariate Shapiro-Wilks test. We had an equal number of groups and small sample sizes, and thus homogeneity of variancecovariance (Box $M$ test) was not tested and LDAs (MASS R package; Venables \& Ripley 2002) were chosen over quadratic discriminant function analysis. Adult shell LDAs were run in backward stepwise fashion using the stepclass function in 'klaR' package in $\mathrm{R}$ (Roever et al. 2018) to determine the suite of elements to include in the final models. Larval and settled shell of spat LDAs were run in a forward stepwise fashion using the Wilks lambda statistic to determine the order of variable entry, and F-statistic probabilities were used to evaluate model improve- ment using the 'klaR' package in $\mathrm{R}$ (Roever et al. 2018). Backward LDAs did not perform well in spat analyses because of high collinearity among most TE ratios. Prior to running final LDAs, MANOVAs were run using Pillai's trace test statistic to ensure site separation in multi-elemental TE ratios to validate the use of an LDA. Prior probabilities were computed with equal group sample sizes for all LDAs. Jackknife reclassification success was used to determine classification accuracy (i.e. the success rate of the LDA to assign shells to a site). Standardized coefficients were used to assess the relative contribution of each TE ratio to determining site separation. Because the LDA model was forced to predict all larvae to a potential sampled spawning site while not all potential spawning sites in the system were sampled, when we assigned larvae to a natal source (i.e. adult shell proxy source), any larvae with a group probability $>0.9$ had a strong likelihood of originating from the predicted site (Gomes et al. 2016). All analyses were conducted in RStudio v.1.1.453 and R v.3.5.0 (R Core Team 2017).

\section{RESULTS}

\subsection{Spat settlement}

\subsubsection{Spatial and temporal variation}

Settlement was higher in 2016 (mean and maximum settlement: $70 \pm 19$ and 1137 spat plate $^{-1}$, respectively) than 2014 (18 \pm 6 and 174 spat plate ${ }^{-1}$, respectively). In both years, settlement was higher in EMS than MB. MB sites had up to $1 \pm 1$ spat plate ${ }^{-1}$ in 2014 and up to $25 \pm 11$ spat plate ${ }^{-1}$ in 2016. In 2014, spat settlement exponentially increased westward from MB6 to EMS1, with the highest settlement at the westernmost site, EMS1 $\left(34 \pm 14\right.$ spat plate ${ }^{-1}$; Fig. 3A). In 2016, spat settlement did not increase continuously westward because settlement at MB1 (56 \pm 23 spat plate $^{-1}$ ) was as high as that at EMS1 (54 \pm 23 spat plate $^{-1}$ ) (Fig. 3A). EMS3, sampled only in 2016, had the highest settlement $(200 \pm 91$ spat plate $^{-1}$ ). Spat settlement increased exponentially westward from MB7 to EMS3, shifting peak settlement from west to east EMS in 2016 compared to 2014. Previous studies conducted in the MB-EMS system also showed patterns of increasing settlement westward but reported higher maximum settlement than found in this study (Fig. 3B).

An exponential increase in spat settlement began in mid-July 2014 (Day 192) and 2016 (Day 234) 


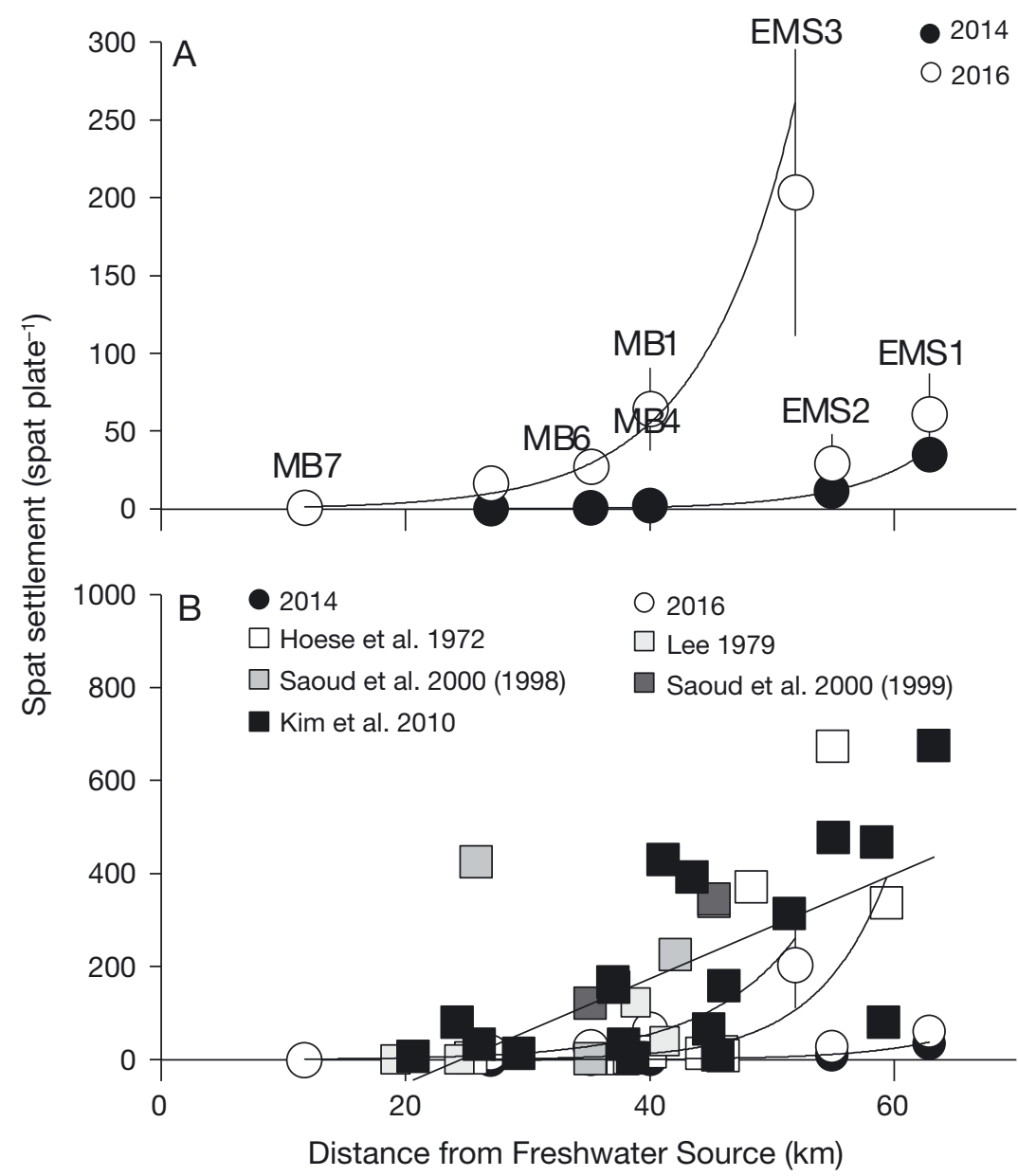

Fig. 3. (A) Average spat settlement (circles) versus distance from freshwater input (i.e. head of Mobile Bay) and standard errors (vertical bars) per settlement plate collected from mid-May (Day 150) to mid-August (Day 234) in 2014 and from mid-May to mid-September (Day 262) in 2016 and (B) average spat settlement from previous studies in the Mobile Bay-eastern Mississippi Sound system (squares) compared to the current study (circles). Settlement this study 2014: $\log (y)=0.06 x-2.46 ; \mathrm{R}^{2}=0.99, F_{1,3}=254.5, \mathrm{p}<0.001$ and 2016: $\log (y)=$ $0.06 x-0.53 ; R^{2}=0.97, F_{1,3}=102.8, p<0.01$. Hoese et al. $(1972): \log (y)=0.08 x$ $-1.90 ; \mathrm{R}^{2}=0.68, F_{1,8}=17.01, \mathrm{p}<0.01 ; \mathrm{Kim}$ et al. $(2010): y=11.25 x-275.31 ; \mathrm{R}^{2}$ $=0.45, F_{1,16}=12.94, \mathrm{p}<0.01$. One data point $(-88.1,1541)$ from Saoud et al. 2000 (1999) is not shown for scaling clarity

(dashed lines in Fig. 4). In 2014, site and week were the most important drivers of the increase in settlement (negative binomial GLM: deviance $=$ $49 \%$; dispersion parameter $=0.58$ ). Similarly, site and week in 2016 were the most important drivers of the increase in settlement (zero-altered negative binomial GLM: McFadden's pseudo $\mathrm{R}^{2}=0.13$; dispersion parameter $=0.62$ ). In both years, oyster settlement increased exponentially with time at similar rates (slope $=0.38$ in 2014 and 0.34 in 2016) at all sites, but intercepts differed among sites (Table S2, Fig. 4).

\subsubsection{Environmental attributes}

Freshwater discharge differed between years $\left(F_{1,303}=93.03\right.$, effective $\mathrm{df}=8.29, \mathrm{p}<0.0001$, Gaussian process smoother). In both years, discharge was highest at the beginning of the sampling period, with discharges of $3000-5000 \mathrm{~m}^{3} \mathrm{~s}^{-1}$ in MayJune of 2014 and $\sim 2500 \mathrm{~m}^{3} \mathrm{~s}^{-1}$ in early May of 2016 and discharges for the remaining sampling periods $<1500$ and $<1000 \mathrm{~m}^{3} \mathrm{~s}^{-1}$, respectively (Fig. 5A). In both years, winds were primarily SW and SE with speeds of 3-6 $\mathrm{m} \mathrm{s}^{-1}$, and leading up to the settlement events, winds were primarily SW (Fig. S1).

Salinity (2014) and temperature (2014 and 2016) varied little among sites that had detectable settlement (Fig. 5A; salinity $2014: F_{2,14}=2.42, \mathrm{p}=$ 0.13 ; temperature $2014: F_{2,14}=0.20, \mathrm{p}=$ 0.82 ; temperature $2016: F_{5,47}=0.11, \mathrm{p}=$ 0.99). In 2014, salinity at all sites increased linearly with time, while in 2016, salinity increased linearly with time with the same slope (0.34) at all sites but with different intercepts for different sites (Table S3). Among the sites tested when comparing 2014 and 2016 salinity data (EMS1, EMS2, MB1), there was a significant interaction between year and week $\left(F_{1,32}=\right.$ $25.17, \mathrm{p}<0.0001)$. For every 2 wk period, there was a $1.4 \times$ greater increase in salinity in 2014 compared to 2016, driven by the higher discharge and resulting lower salinity in MayJune of 2014 (Figs. 5 \& S2, Table S4) and the sustained low discharge in July-August that increased salinity to comparable values in August of both years. Additionally, modeled salinities were lower in the MB-EMS system in 2014, when salinities within MB were rarely $>10$ in May-June (Fig. 6). Temperature differed between years $(t=2.36, \mathrm{p}=0.01)$ and was lower at the beginning of $2014\left(26^{\circ} \mathrm{C}\right)$ than in $2016\left(29^{\circ} \mathrm{C}\right)$ (Fig. 5B).

Salinity generally increased prior to potential spawning and settlement events, while temperature changed little before either event. During the 2 wk period in mid to late June (Days 164-178), prior to the estimated spawning event in 2014, salinity and 


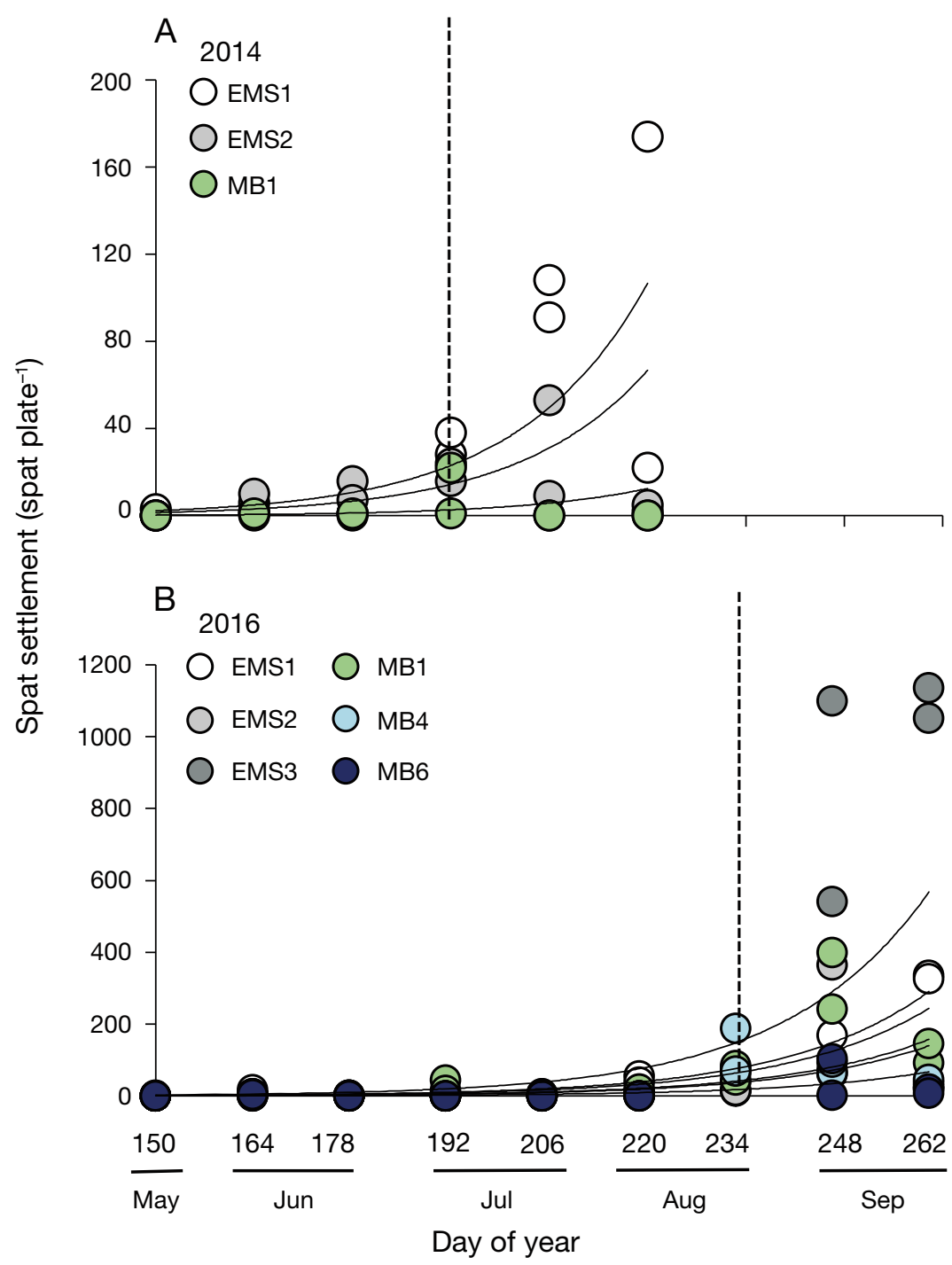

Fig. 4. Spat settlement per settlement plate during (A) 2014 and (B) 2016, showing only the sites that had appreciable settlement. Dashed vertical lines: time points of the beginning of consistent settlement at all sites. Settlement increased exponentially with time at all sites with similar slopes (2014 negative binomial regression: slope $=0.38, z=5.19, \mathrm{p}<0.0001 ; 2016$ zero-altered negative binomial regression: slope $=0.34, z=10.59, p<0.0001$ ), but different intercepts among sites (Table S2)

temperature increased 9.5 units and $1.8^{\circ} \mathrm{C}$, respectively (Fig. 5). Similarly, during the $2 \mathrm{wk}$ period in late June to mid-July (Days 178-192) prior to beginning of the subsequent 2014 exponential increase in settlement (settlement event), salinity increased 4.2 units and temperature dropped by $1^{\circ} \mathrm{C}$. The modeled results also indicated salinity increased in 2014 prior to the settlement event, with salinities throughout MB and EMS $<10$ and $<15$, respectively, before the event but $\sim 20$ in EMS during the settlement period (Fig. 6A). In 2016, 2 wk prior to the estimated spawn- ing event (June to early July, Days 206-220), salinity increased by 3.7 units among all settlement sites and temperature was stable within $0.1^{\circ} \mathrm{C}$. Conversely, during the 2 wk before the 2016 settlement event (mid to late July, Days 220-234), salinity decreased by 2.9 units at all sites except for one of the westernmost sites in EMS (EMS2; Fig. 5), and temperature was stable within $0.2^{\circ} \mathrm{C}$. In contrast to YSI measurements, the modeled salinities in 2016 rose leading up to the settlement event on Day 234, with salinities ranging from 10-25 in lower MB and 25-30 in EMS during this time (Fig. 6B). While YSI measurements did not detect large temperature variations, finer resolution hourly buoy temperature data located at a site representative of temperature throughout the system showed a 3.5 and $1^{\circ} \mathrm{C}$ decrease in 2014 and 2016, respectively, during the 2 wk prior to potential spawning events, and a 3 and $4^{\circ} \mathrm{C}$ temperature increase in 2014 and 2016, respectively, during the $2 \mathrm{wk}$ before the settlement events (Fig. S3).

\subsection{TES}

\subsubsection{TE ratios among shell types}

TE ratios differed among shell types (larval, settled, recent, whole; Fig. 7). When comparing larval versus settled shell TE ratios, differences were seen between larval and settled shells of spat and among sites for all 3 time periods tested (all MANOVAs: $\mathrm{p}<0.001$; Table S5), with Sr being the only element to differ among sites for all time periods tested (Table S6). Accordingly, TE ratios differed between larval and settled shells for all elements except $\mathrm{Cu}$ in May-June, $\mathrm{Mg}$ and $\mathrm{Sr}$ in July-August, and all elements except $\mathrm{Mn}, \mathrm{Cu}$, and $\mathrm{Sr}$ in August-September. TE ratios differed among sites for $\mathrm{Mg}, \mathrm{Mn}, \mathrm{Co}$, and $\mathrm{Sr}$ in May-June, all elements in July-August, and $\mathrm{Sr}$ in August-September. Sites that drove the spatial elemental differences were MB1 (at historical reef sites) in May-June and July-August, EMS3 in July-August, and EMS2 in August-September. 

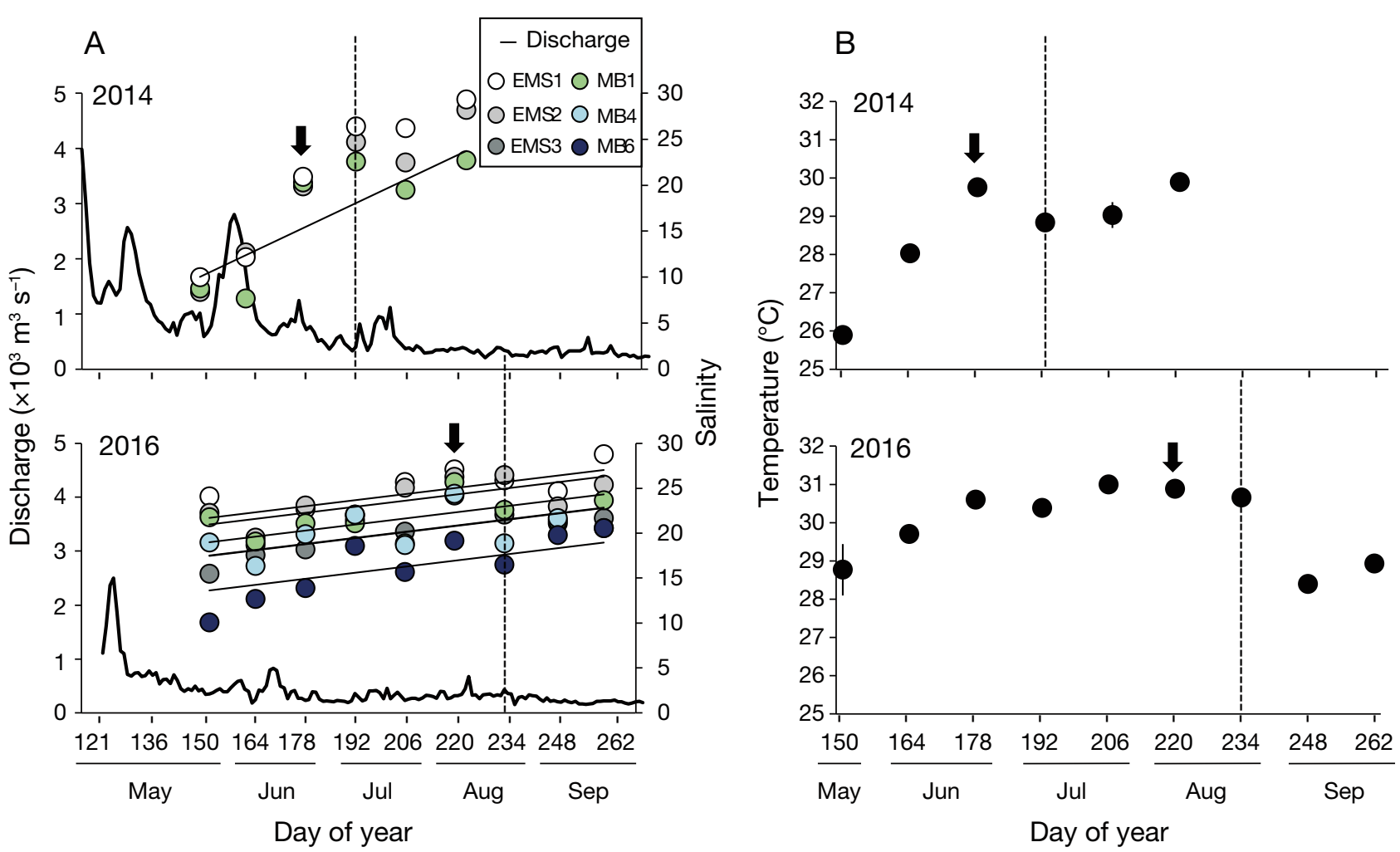

Fig. 5. Freshwater discharge input and (A) salinity and (B) temperature for 2014 and 2016. Because temperature did not differ among sites, each temperature data point represents a spatial average of all sites (cf. Fig. 4). Salinity $2014: y=1.83 x+4.36$; $F_{3,14}=25.85, \mathrm{p}<0.0001$. Salinity 2016 regression statistics shown in Table S3. Arrows indicate estimated spawning events, and dashed lines indicate the subsequent start of an exponential increase in spat settlement

\subsubsection{Site-specific TE signatures}

Larval and settled shell LDAs showed site-specific TE signatures during most of the time periods tested (Fig. 8A,B: only time periods with significant MANOVAs are shown). TE ratios in larval shells differed among sites (i.e. distinct natal sites) in May-June (MANOVA: $\mathrm{p}<0.001$ ) and August-September (MAN OVA: $p=0.02$; Table S7). TE ratios in settled shells differed among sites (i.e. distinct settlement locations) in July-August and August-September (MANOVAs: $p<0.001$ ). Larval shell site differences in May-June and August-September were driven by differences in $\mathrm{Sr}$ and $\mathrm{Ni}$ (LD1 explaining $70 \%$ of site variation) and Mn and Sr (LD1 explaining $62 \%$ of site variation), respectively, while settled shell site differences in July-August and August-September were driven by differences in $\mathrm{Sr}$ and $\mathrm{Cu}$ (LD1 explaining $60 \%$ of site variation) and Sr and V (LD1 explaining $75 \%$ of site variation), respectively (Fig. 8A,B; Table S8).

Adult shell (recent and whole) LDAs showed sitespecific TE signatures, with better site distinction for recent shells, representing incorporation of TE ratios throughout the spawning season (Fig. 8C). Accordingly, TE ratios in shells of adult oysters differed among sites (MANOVAs: $p<0.001$; Table S9, Fig. 8C) with recent shell site differences driven by differences in $\mathrm{Sr}$ and $\mathrm{Fe}$ (LD1 explaining $69 \%$ of site variation), and whole-shell site differences driven by Sr and Mg (LD1 explaining 79\% of site variation; Table S10).

\subsubsection{Temporal variation in site-specific TE signatures}

Larval and settled shells had different site separation patterns (Fig. 8A,B) and classification successes (Table S11) during each of the 3 time periods tested, indicating that TE signatures varied over multiple months. For example, larval (May-June) and settled (August-September) shell differed in site separation (Fig. 8A,B) and were temporally variable (classification [100 and $89 \%$, respectively] and jack-knifed reclassification [73 and $67 \%$, respectively] success; Table S11). 
A 2014 Prior to spawning
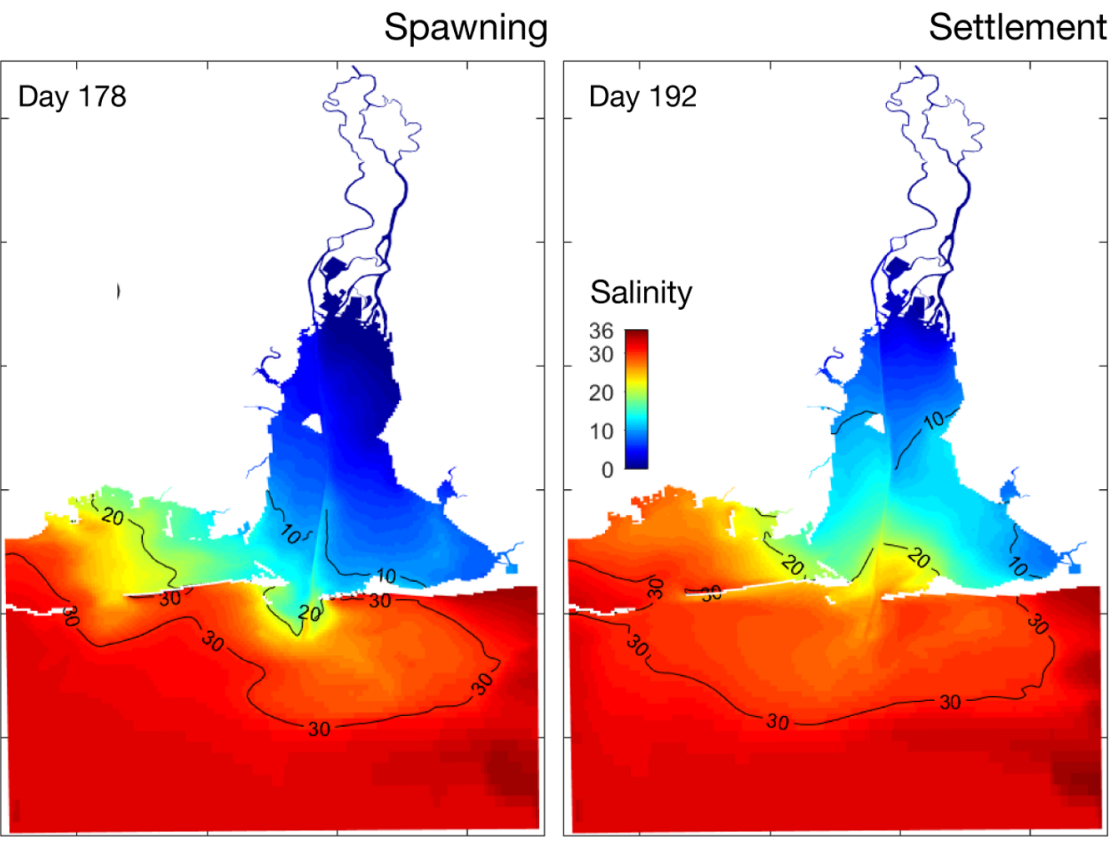

\section{B 2016}
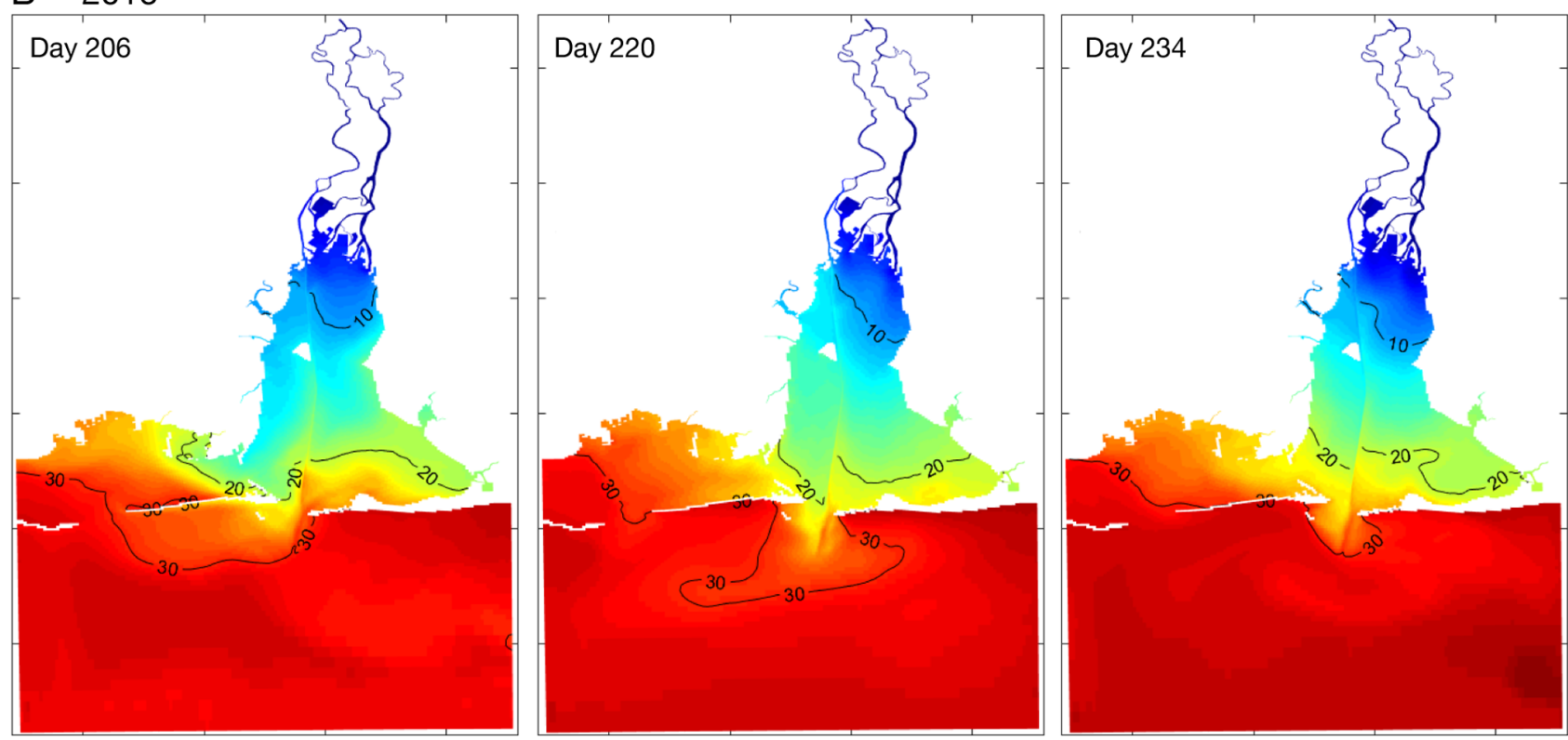

Fig. 6. Model results for salinity conditions of the Mobile Bay-eastern Mississippi Sound system leading up to the beginning of an exponential increase in spat settlement for (A) 2014 and (B) 2016, including salinity conditions 2 wk prior to the potential spawning event (4 wk prior to increased settlement) (left panels), during the potential spawning event (middle), and at the initial increase in settlement (right)

Recent and adult shells also had different site separation patterns (Fig. 8C) and classification successes (Table S12), indicating that TE ratios varied from yearly (recent shell) to multi-year (whole shell) scales (classification [100 and 96\%, respectively] and jackknifed reclassification [74 and $63 \%$, respectively] success; Table S12).

\subsubsection{Larval predictions}

Larval origins were only predicted for the MayJune time period because TE ratios had the most differentiation among sites for this period. In recent adult shells, TE ratios used for larval predictions differed among sites (MANOVA: $p<0.001$; Table S13) 

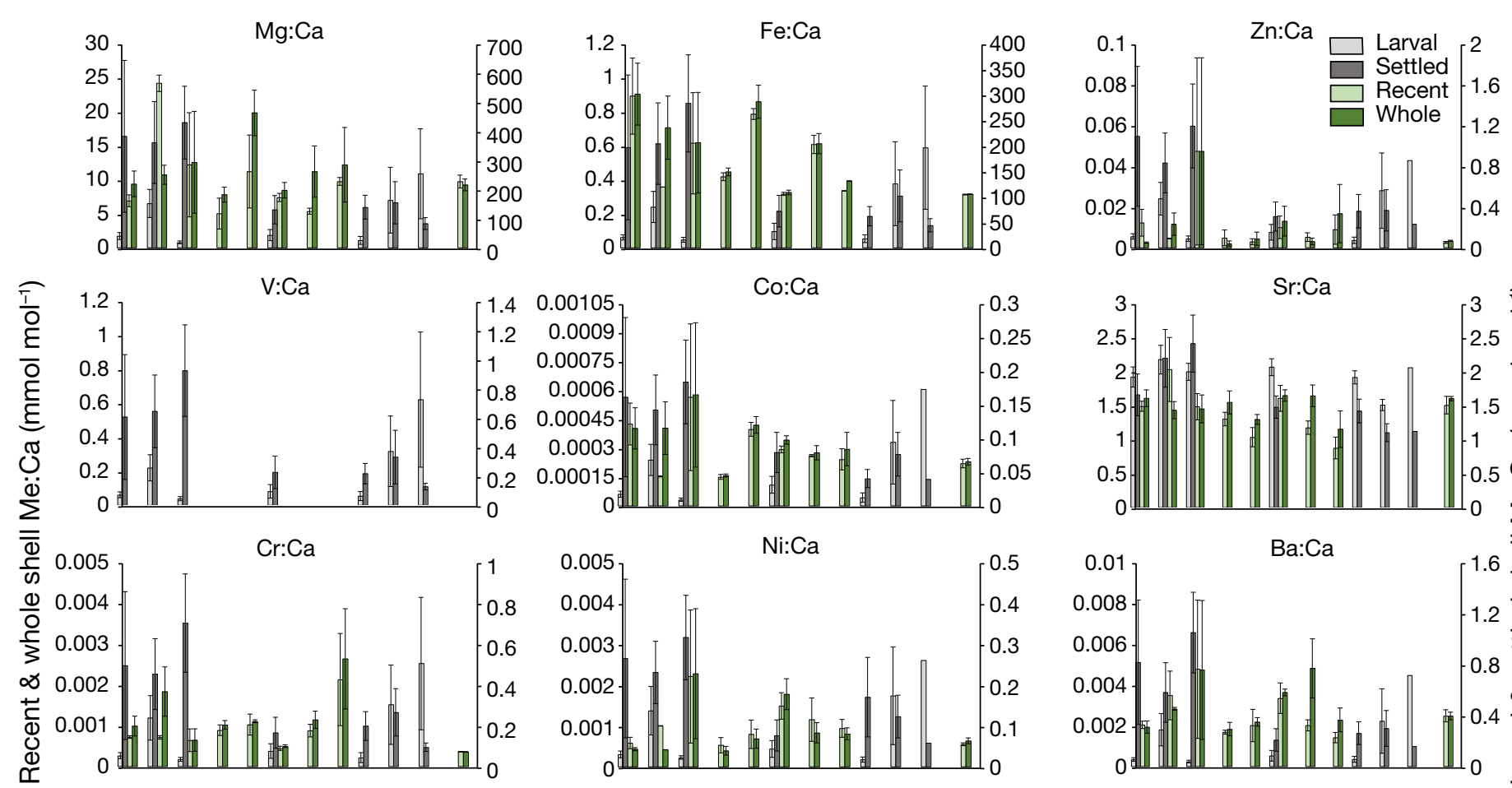

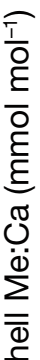
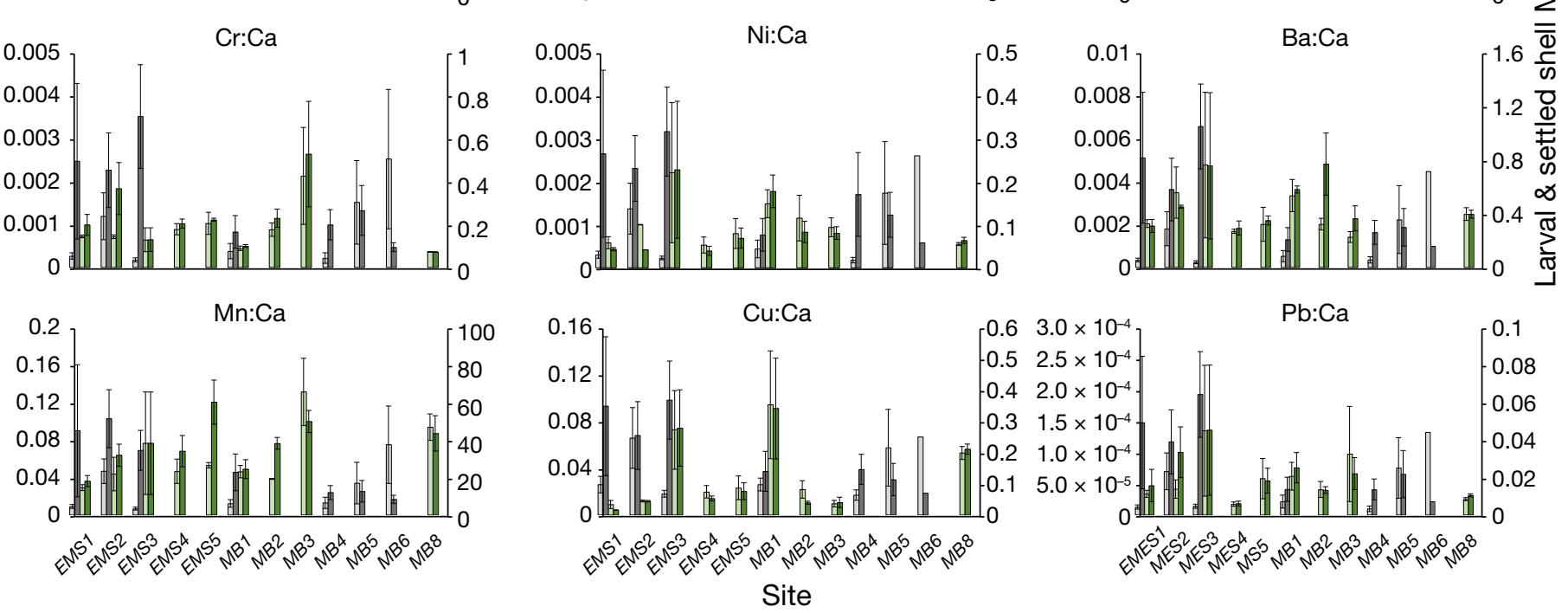

$\mathrm{Pb}: \mathrm{Ca}$

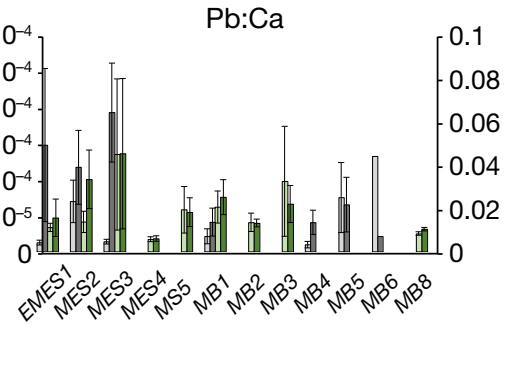

Fig. 7. Trace element ratios $\left(\mathrm{mmol} \mathrm{mol}{ }^{-1}\right)$ in larval and settled shells of spat (secondary axes) and recent and whole adult shells (primary axes) at each site. Ratios represent averages of all time periods measured: spat shells averaged May-September, recent shells represent an average of approximately a single year, and whole shell represents a multi-year average. $\mathrm{V}$ was only measurable in spat shells. Spat and adult shells were present at EMS1-3 and MB1; spat shells only were present at MB4-6; adult shells only were present at EMS4-5, MB2-3, and MB8

(classification [92\%], jack-knifed reclassification [54\%]; Table S14, Fig. S4), indicating that adult shells could potentially be used as a proxy for natalsite TE ratios. Recent shell site differences were driven by differences in Sr (LD1 explaining $71 \%$ of site variation; Table S15). All larvae that settled at site EMS1 were predicted to originate from site EMS1 (probability > 0.9; Table 1). Additionally, some larvae from sites EMS3, MB4, and MB5 were predicted to originate from site EMS1 (probability $>0.8$ ).

\section{DISCUSSION}

Exploration of settlement and connectivity can provide insight into the persistence of larval spe- cies under differing freshwater regimes. Settlement throughout the MB-EMS system differed between the 2 years (i.e. high and low discharge years). High discharge during 2014 resulted in lower overall settlement, possibly due to lower survival and flushing of larvae out of the system, while oyster settlement was higher and more widespread during the low discharge year (2016). While we would have liked to test connectivity in both years, high discharge in 2014 resulted in larval shells that were too fragile for TE analyses. Additionally, while our results for larval predictions should be taken with caution due to the use of classifying larvae to adult shell, predictions did indicate EMS as an important larval source, which is in line with settlement results (i.e. settlement was highest in EMS for both years) and previous studies, 

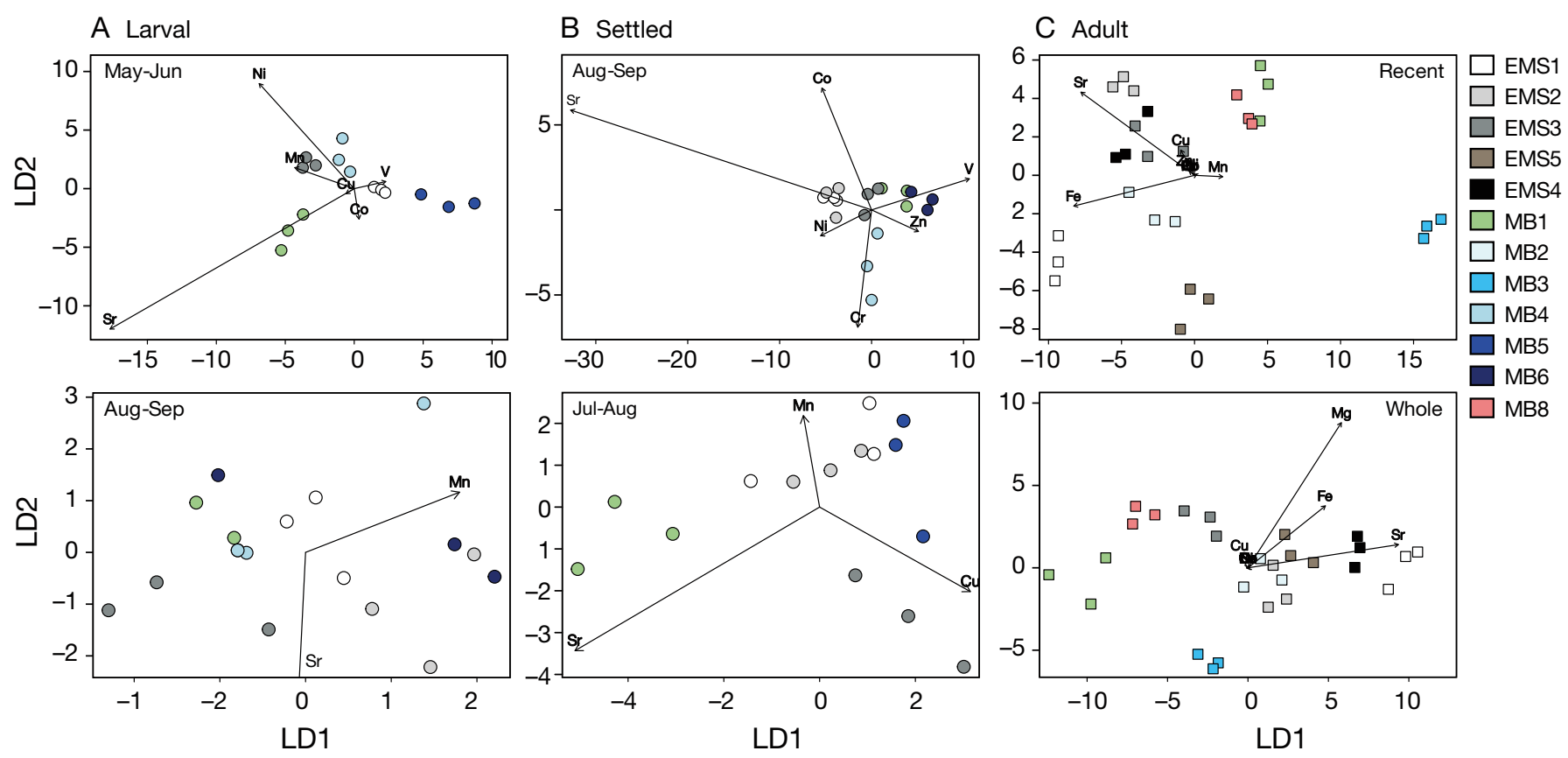

Fig. 8. Linear discriminant (LD1, LD2) function analyses of (A) larval, (B) settled, and (C) adult shell. The larval and settled panels show time periods that had different trace element (TE) ratios among sites (i.e. significant MANOVAs); May-June (top) and August-September (bottom) for larval shell; August-September (top) and July-August (bottom) for settled shell. Sr arrow LD2 (-15.38) is cut off from August-September larval biplots (cf. Tables S8 \& S10 for full linear discriminants). The adult shell panels show recent shell (top) representing approximately a single year and whole shell (bottom) representing multiple years. Arrows indicate TE ratios causing site differences

showing the promise of this method. Furthermore, if our connectivity results are to be trusted, we can postulate that connectivity was likely reduced in the

Table 1. Predictions of larval origins (May-June 2016) from the larval origin prediction linear discriminant function analysis using trace element (TE) ratios in recent adult shell (i.e. proxy for natal site TE ratios). Site indicates spat collection site and predicted site indicates adult shell collection site where larvae were predicted to originate from. Probability of group classification is the probability of larvae correctly originating from a site. Bold indicates the highest probability of site origination and thus indicates the predicted site. Each row represents an individual larva shell

\begin{tabular}{|c|c|c|c|c|c|c|c|c|c|}
\hline \multirow[t]{2}{*}{ Site } & \multirow{2}{*}{$\begin{array}{l}\text { Predicted } \\
\text { site }\end{array}$} & \multicolumn{8}{|c|}{ - Probability of group classification } \\
\hline & & EMS1 & EMS2 & EMS3 & EMS4 & EMS5 & MB1 & MB2 & MB3 \\
\hline EMS1 & EMS1 & 0.99 & 0 & 0 & 0 & 0 & 0 & 0 & 0.01 \\
\hline EMS1 & EMS1 & 0.97 & 0 & 0 & 0 & 0.01 & 0 & 0 & 0.02 \\
\hline EMS1 & EMS1 & 0.96 & 0 & 0 & 0 & 0.01 & 0 & 0 & 0.03 \\
\hline EMS3 & EMS5 & 0.02 & 0 & 0 & 0 & 0.47 & 0 & 0.12 & 0.39 \\
\hline EMS3 & EMS5 & 0.05 & 0 & 0 & 0 & 0.48 & 0 & 0.1 & 0.36 \\
\hline EMS3 & EMS1 & 0.87 & 0 & 0 & 0 & 0.03 & 0 & 0 & 0.1 \\
\hline MB1 & MB2 & 0.02 & 0 & 0 & 0 & 0.15 & 0 & 0.76 & 0.06 \\
\hline MB1 & MB2 & 0.03 & 0 & 0 & 0 & 0.19 & 0 & 0.65 & 0.13 \\
\hline MB1 & MB1 & 0 & 0 & 0.22 & 0 & 0 & 0.58 & 0.2 & 0 \\
\hline MB4 & EMS1 & 0.8 & 0 & 0 & 0 & 0.08 & 0 & 0 & 0.12 \\
\hline MB4 & EMS1 & 0.67 & 0 & 0 & 0 & 0.17 & 0 & 0.01 & 0.15 \\
\hline MB4 & MB3 & 0.2 & 0 & 0 & 0 & 0.33 & 0 & 0.03 & 0.45 \\
\hline MB5 & MB3 & 0.06 & 0 & 0 & 0 & 0.34 & 0 & 0 & 0.6 \\
\hline MB5 & EMS1 & 0.58 & 0 & 0 & 0 & 0.12 & 0 & 0 & 0.3 \\
\hline MB5 & EMS1 & 0.98 & 0 & 0 & 0 & 0 & 0 & 0 & 0.02 \\
\hline
\end{tabular}

high discharge year compared to low discharge year, where it is likely that only a few reefs in the system were spawning, as evidenced by lower and more spatially confined settlement in 2014 . These results have implications for the long-term settlement and larval connectivity of this system, especially as climate change introduces large-scale changes in precipitation and runoff patterns to coastal systems (Vörösmarty et al. 2000).

\subsection{Spat settlement}

Larval transport processes are inherently stochastic (Pineda et al. 2007) and result in variable spatial and temporal larval settlement patterns (Siegel et al. 2008). Accordingly, oyster settlement in the MB-EMS system was variable among sites, through sampling seasons, and between years, showing overall patterns similar to previous observations (Hoese et al. 1972, Lee 1979, Saoud et al. 2000, Kim et al. 2010). Collectively, this study 
and previous observations indicate a persistent gradient of increasing spat settlement westward from MB into EMS during the past $\sim 40$ yr (Fig. 3B). In this study, however, peak settlement was lower overall than in previous studies, with the highest settlement within EMS in a known productive commercial harvesting area in Alabama (EMS3; VanderKooy 2012). Kim et al. (2010) also observed highest settlement in this commercial harvesting area during one yearly survey, while the remaining surveys had highest settlement in western EMS. Similarly, Saoud et al. (2000) found $7 \times$ greater spat settlement in this harvesting area in 1999 compared to 1998 but did not measure settlement in EMS, limiting conclusions about EMS settlement during that time (Fig. 3B).

Settlement timing (June-October) also occurred within the range reported in other studies in the MB-EMS system (Hoese et al. 1972, Lee 1979, Saoud et al. 2000, Kim et al. 2010). Observed peak settlement coincided with published summer peaks (late July-early August) in settlement (Hoese et al. 1972, Lee 1979, Saoud et al. 2000). Other published studies have reported summer and fall peaks in settlement. While this study did not assess fall settlement, we did find peak settlement occurring in late July and late September in 2014 and 2016, respectively. In this study, spat settlement did not taper off during the sampling periods in either year, even through the end of September during 2016, suggesting that additional settlement could have occurred later in the season. While variability in the timing and location of spawning and number of larvae necessarily influence interannual variation in settlement, this and previous studies suggest that spatial and temporal settlement patterns within the MB-EMS system have been largely consistent across decades. Yet lower spat settlement observed in recent compared to previous years may lead to a loss of oysters in the future if settlement continues to decline.

Changes in salinity in response to varying freshwater discharge conditions in 2014 and 2016, and to a lesser extent in temperature, likely contributed to differences in settlement and potentially spawning patterns during this study. Changes in salinity and temperature preceded spawning and peak settlement by 2-4 wk, consistent with findings in previous studies (Hoese et al. 1972, Hayes \& Menzel 1981). Specifically, a salinity increase of 4-10 in both years and a temperature increase of $2^{\circ} \mathrm{C}$ in 2014 prior to the potential spawning event likely triggered spawning in the MB-EMS system. Furthermore, settlement in the high discharge year (2014) was only seen in EMS potentially because high discharge transported lar- vae westward (Kim et al. 2013) and/or spawning and survival of larvae were limited in lower salinity areas of the MB-EMS system (Gancel et al. 2019). In contrast, during the low discharge year (2016) settlement was higher and more spatially widespread. Thus, the spatial and temporal scale of settlement changed between low and high discharge years.

It is important to note that the discharge rates, salinities, and corresponding temperatures measured in 2014 and 2016 do not represent historical extremes. The observed environmental conditions were within the ranges reported in previous settlement studies in the MB-EMS system (Hoese et al. 1972, Lee 1979, Saoud et al. 2000, Kim et al. 2010). Lower spat settlement under typical environmental conditions could indicate a loss of broodstock or a lack of suitable substrate for settlement. Future studies also could consider other environmental factors, such as $\mathrm{pH}$ and dissolved oxygen, which may be linked to freshwater discharge or interact with salinity (Patterson \& Carmichael 2018) to affect survival and are of growing importance to larval demographics in global oceans (Peguero-Icaza et al. 2011, Gerber et al. 2014).

\subsection{TEs}

TE ratios recorded in oyster shells showed distinct site signatures, meaning that shells collected from certain sites could be distinguished from one another. Settled shell TE ratios could distinguish sites $11 \mathrm{~km}$ apart (e.g. MB1 and MB4), while adult shell TE ratios could distinguish sites $2.5 \mathrm{~km}$ apart (e.g. EMS1 and EMS2) (Table 2, Fig. 8). While larval shells also had distinct site TE ratios, we cannot conclude that this result is representative of larval collection sites because larvae were likely transported during their larval stage, homogenizing TE signatures from various locations. Thus, without larval incubation experiments to ground-truth these results, caution should be given to our larval shell spatial results. Furthermore, larval and settled shell sites were harder to distinguish from one another using TE ratios, as evidenced by the similarity of TE ratios among multiple sites (Fig. 8A,B). This could be explained by collinearity of TE ratios in larval and settled shells, possibly due to high freshwater input into the system, which is known to increase variation in TE ratios due to mixing of environmental gradients (Miller et al. 2013a, Kroll et al. 2016). Spat shells likely were more affected by changes in freshwater input compared to adult shells due to (1) a shorter time spent ( 2-3 wk 


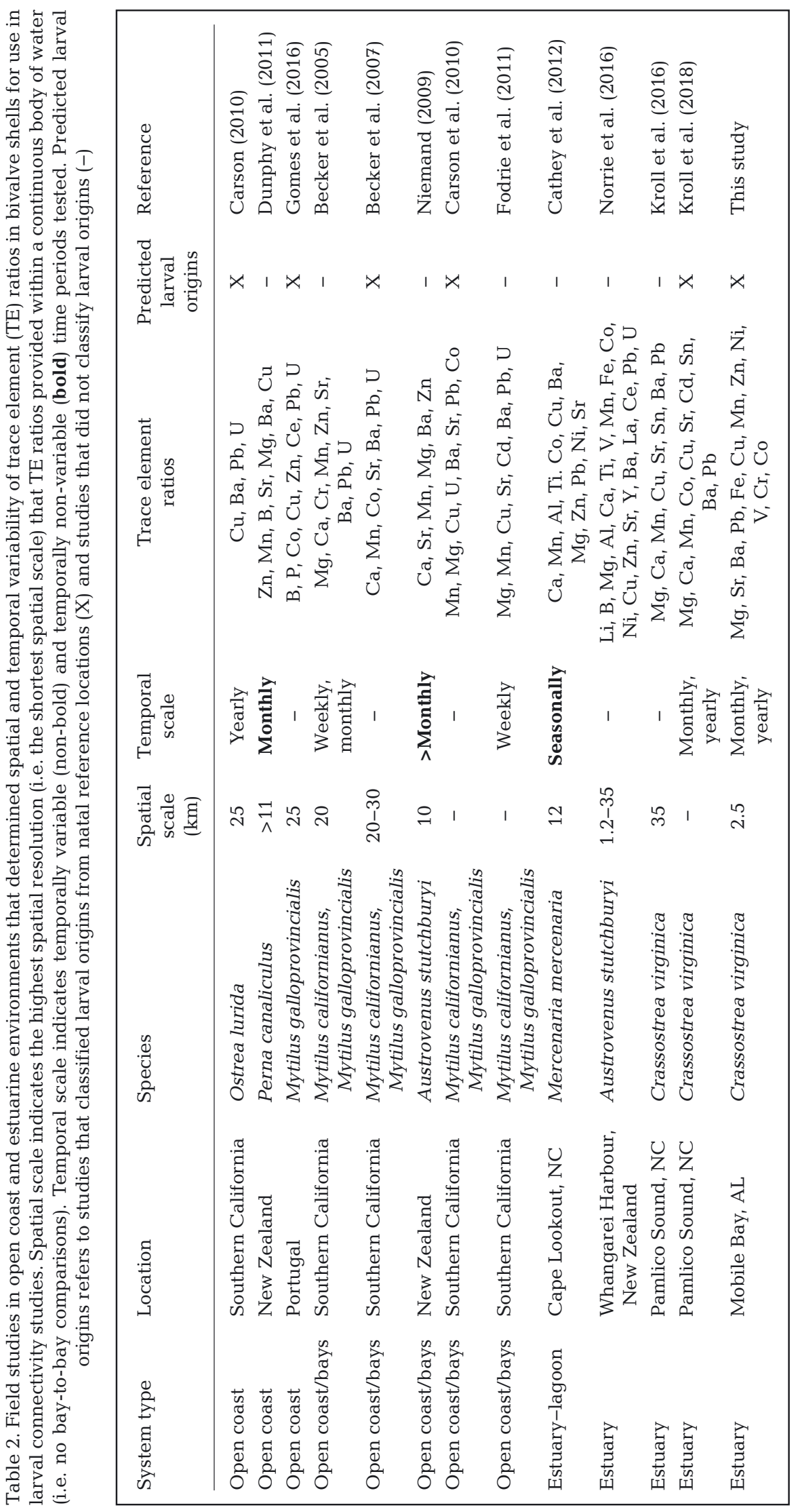

larval period) in the environment resulting in less reliable incorporation of elements into the shell and (2) a larval stage that experiences multiple water masses during transport increasing the likelihood of encountering freshwater and potentially homogenizing TE signatures (Miller et al. 2013b). Other factors that may affect TE resolution in spat shells by affecting intake, assimilation, and retention of elements among sites include (1) growth rate and physiological state, such that higher elemental incorporation occurs at faster growth rates (Carré et al. 2006) and no elemental uptake occurs during growth cessation (Schöne 2008); (2) food composition that influences the availability of elements for incorporation into shell (Thébault et al. 2009); (3) shell matrix composition, because elements are incorporated differently between calcite and aragonite (Lorens \& Bender 1980, Weiss et al. 2002) and (4) ontogenetic shifts (Strasser et al. 2008, Génio et al. 2015).

Sr concentration, which has been documented to vary with salinity in taxa in many systems, consistently contributed to site separation in this study. Sr was the most important TE ratio in larval and settled shells of spat to discriminate among sites in this study, and Sr was not correlated with other TE ratios. No collinearity between $\mathrm{Sr}$ and other elements suggests Sr was likely incorporated differently than other TEs (Lazareth et al. 2003). Sr is a commonly used salinity indicator (Dodd \& Crisp 1982) despite some variation among study systems and species (e.g. Secor et al. 1995, Kroll et al. 2016). Here, we found that $\mathrm{Sr}$ in settled shells had a weak positive relationship to salinity, but larval shells did not (results not shown: $\mathrm{R}^{2}$ $=0.10, \mathrm{p}=0.05)$, which is not surprising given the potential move- 
ment of larvae across a highly variable salinity gradient in the freshwater-dominated MB-EMS system. Although understanding the cause of TE variation is not a requirement for use of elemental signatures in larval connectivity studies (Gillanders 2002, Carson 2010, Cook et al. 2014), more research on factors affecting Sr incorporation into eastern oyster shells, especially in freshwater-dominated systems, would benefit application of TE for this and other indicator studies (see Lazareth et al. 2003). Localized sources of TE ratios, such as industry, agriculture, groundwater, and river discharge, may further contribute to variation among sites (Charette \& Sholkovitz 2002, Cordi et al. 2003, Carson et al. 2013). Overall, the potential for relatively high variation in TE ratios in larval and settled oyster shells within sites on short timescales (weeks) suggests the need to determine site- and time-specific elemental signatures for each study. This need may be particularly great in freshwaterdominated and urbanized estuaries like the MB-EMS system, which receive elements from multiple and poorly defined upstream sources.

Recent versus whole adult shell also showed different TE ratios, indicating that different TE ratios are incorporated during different time periods (Fig. 8C). Temporal variation in TE ratios makes it difficult to use adult shells as a proxy for natal site signatures because TE ratios change through time and the time period of TE ratio acquisition needs to match up with the larval shell acquisition period. In this study, recent shell, representing roughly $1 \mathrm{yr}$ of growth, was able to provide better classification success and site distinctions than whole shell, representing multiple years of growth. These results are promising because the recent shell represented the current spawning season time period and thus was more representative of TE ratios present in the system during larval transport and settlement than the whole shell. While not perfect due to recent and larval shell integrating different time frames (months versus weeks, respectively), adult shells show some promise for being proxies for natal reference signatures because there was adequate site distinction using recent shells. We recommend that future studies perform larval outplant studies to better define those natal signatures and compare results with adult shells to better assess the utility of adult shells as natal proxies.

\subsection{Larval connectivity}

While our connectivity results should be taken with caution due to mineralogical differences and different integrated time periods between shell types, the use of adult shell as a proxy for natal site reference signatures did provide evidence of probable connectivity patterns between adults and larvae in the MB-EMS system. There was high self-recruitment and recruitment to nearby locations among larvae collected from EMS, where oysters are historically harvested (May 1971) and larval retention is known to be high (Kim et al. 2010, this study). Although self- and nearbyrecruitment was seen among EMS sites, probabilities were highest $(>0.9)$ for the site farthest west in EMS; other predicted sites had probabilities of $>0.5$, indicating potentially high larval mixing in EMS or larvae originating from natal locations outside the study area (Table 1, Fig. 9). Interestingly, larval shells collected from lower and lower-mid MB near the MB ship channel had some larvae predicted to originate from the site farthest west in EMS, suggesting that oysters in EMS are important larval sources to this system and may be the primary source of larval oysters to some of the most productive harvest areas in the Gulf of Mexico (Zu Ermgassen et al. 2012).

Other studies have concluded that larvae are unlikely to pass from west to east MB due to flushing through the mouth. Under certain physical conditions, i.e. low river discharge $\left(<500 \mathrm{~m}^{3} \mathrm{~s}^{-1}\right), \mathrm{S}$ to $\mathrm{SW}$ winds, and tropic tides, however, small numbers of larvae may be transported to the lower-mid MB region against the expected dominant flow pathway (Kim et al. 2013). Conditions during May-June 2016 were conducive for larval transport from EMS to lower-mid MB (discharge: $<298 \mathrm{~m}^{3} \mathrm{~s}^{-1}$; winds: SW $4-8 \mathrm{~m} \mathrm{~s}^{-1}$ ). Additionally, when discharge conditions are $<1715 \mathrm{~m}^{3}$ $\mathrm{s}^{-1}$, tidal transport may be important for the lower MB-EMS (Webb \& Marr 2016), and larvae may use selective tidal stream (i.e. biological) transport to move from EMS to MB across multiple tidal cycles (Wood \& Hargis 1971, Newell et al. 2005). Previous studies concluded that although biological transport is negligible to the overall pattern of larval transport in MB-EMS it does contribute to larval retention in EMS (Kim et al. 2010), which is in line with the results of this study. Thus, a combination of low river discharge, winddriven circulation, and tidal transport could transport larvae from EMS to lower-mid MB according to TEbased model predictions. It is also possible that similarities in the physiochemical environment, such as salinity and temperature, among sites led to difficulty in discriminating sites using the LDA model (54\% jack-knife classification success) or adult shell was not an adequate TE reference signature. Overall, preliminary larval predictions showed self-recruitment and major connectivity to the EMS region. 

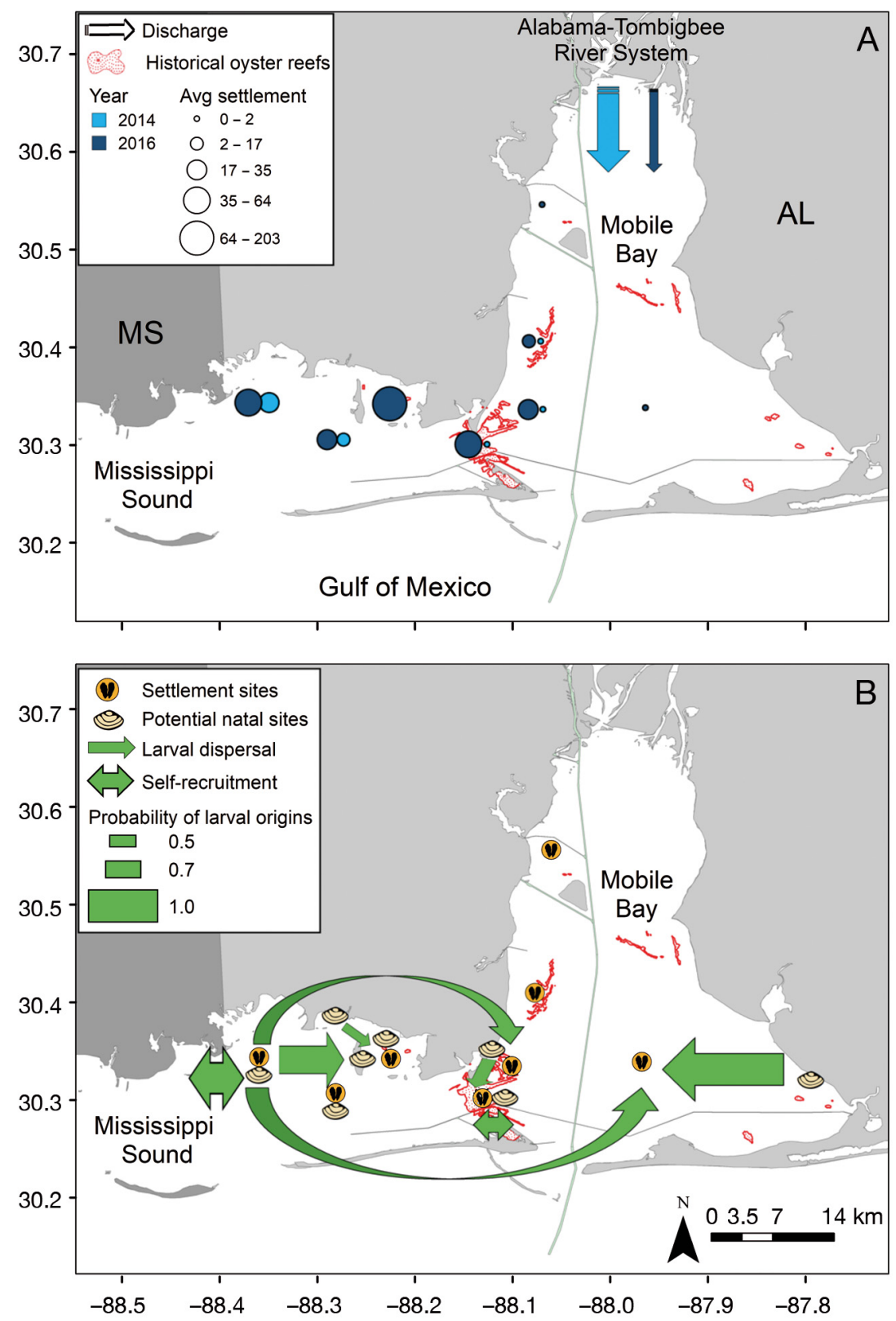

Fig. 9. (A) Summarized spat settlement and freshwater discharge during 2014 and 2016 and (B) hypothesized resulting connectivity patterns for the MayJune 2016 time period when trace element ratios were distinct among sites. In (A), larger circles indicate higher average spat settlement, and thicker hatched arrows indicate higher freshwater discharge. In (B), thicker arrows indicate higher probability of correctly predicting larval origins from a natal site

\section{CONCLUSIONS}

Settlement data in conjunction with geochemical tagging data can provide information on larval origins and population connectivity that are critical to define priority areas for settlement and recruitment in freshwater-dominated estuarine systems. Environ- mental attributes, particularly salinity and temperature, mediated settlement patterns by affecting the magnitude, timing, and location of potential spawning events. In the MB-EMS system, these key environmental attributes were largely driven by freshwater discharge, winds, and tides. Lower overall settlement in recent years, however, suggests a potential for loss of oyster populations through decreased spat settlement and loss of adult oyster habitat, if this trend continues. Higher spat settlement in conjunction with larvae predicted to originate from EMS indicate that the EMS could be an important source of larvae to the region and may be of special interest for future restoration or propagation efforts. This work highlights that a combined biological and geochemical approach can help identify and predict how subsequent adult distributions may change through time in highly dynamic environments. This study provides a baseline and approach for monitoring this type of future change in the MB-EMS system that can be applied to other regions of the world where freshwater inputs are high or increasing due to habitat alteration or climate change.

Due to global changes in precipitation patterns, melting of ice due to warming temperatures, and anthropogenic water diversions, freshwater inputs to coastal systems are expected to change substantially in coming years (Milliman et al. 2008, Dai et al. 2009). Large-scale increases in freshwater discharge into already freshwater-dominated systems may push suitable salinity habitat farther down-estuary, reducing or altering recruitment and connectivity patterns of many species with salinity-dependent pelagic larval stages (Powell et al. 2003, Shoji et al. 2006). Conversely, decreases in freshwater discharge to estuarine environments can cause saltwater intrusion and also change the salinity regime and habitat for salinity-dependent pelagic larval stages (e.g. Apalachicola Bay, Wilber 1992; San Francisco Bay, Cloern \& Jassby 2012). This 
study demonstrates how changes in freshwater discharge between years can result in different settlement patterns. Studies looking at the persistence of commercially important species that have pelagic larval stages need to consider how future long-term changes to freshwater inputs will affect long-term settlement and connectivity.

Acknowledgements. This work was funded by the Mississippi-Alabama Sea Grant Consortium (project number \#R/SFA-03) and the Food and Drug Administration and MESC/Dauphin Island Sea Lab Collaboration (award numbers: 5U19FD005923-04 and 5U19FD004277-04). We thank the US Food and Drug Administration Gulf Coast Sea Food Laboratory, specifically Kevin Calci and George Doup, for boat and field assistance. A special thanks to Kayla P. DaCosta for analytical help with the LA-ICP-MS and thought-provoking conversations about trace element analyses and to Carl Cloyed for statistical assistance. We thank DISL's technical support staff, including Renee Collini, Yantzee Hintz, Grant Lockridge, and Laura Linn for mooring design ideas and construction help. We thank all the Carmichael Lab members, interns, and volunteers for field and laboratory help: Elizabeth Hieb, Casey Fulford, Ashley Frith, Audrey Palombo, Neil Burglund, Jamie Thompson, Victoria Drumm, and Max Han. We also thank Jacob Blandford and The Nature Conservancy for providing adult oysters from TNC reefs. The manuscript was greatly improved by 2 reviewers.

\section{LITERATURE CITED}

Alabama Department of Conservation and Natural Resources (2001) Survey of oyster reefs in Portersville Bay, Alabama. Unpublished report compiled by M Van Hoose

Anastasia JR, Morgan SG, Fisher NS (1998) Tagging crustacean larvae: assimilation and retention of trace elements. Limnol Oceanogr 43:362-368

Beck MW, Brumbaugh RD, Airoldi L, Charranza A and others (2011) Oyster reefs at risk and recommendations for conservation, restoration, and management. BioScience 61:107-116

Becker BJ, Fodrie FJ, McMillan PA, Levin LA (2005) Spatial and temporal variation in trace elemental fingerprints of mytilid mussel shells: a precursor to invertebrate larval tracking. Limnol Oceanogr 50:48-61

Becker BJ, Levin LA, Fodrie FJ, McMillan PA (2007) Complex larval connectivity patterns among marine invertebrate populations. Proc Natl Acad Sci USA 104:3267-3272

Bradbury IR, DiBacco C, Thorrold SR, Snelgrove PVR, Campana SE (2011) Resolving natal tags using otolith geochemistry in an estuarine fish, rainbow smelt Osmerus mordax. Mar Ecol Prog Ser 433:195-204

Calabrese A, Davis HC (1970) Tolerances and requirements of embryos and larvae of bivalve molluscs. Helgol Wiss Meeresunters 20:553-564

* Campana SE, Chouinard GA, Hanson JM, Fréchet A, Brattey J (2000) Otolith elemental fingerprints as biological tracers of fish stocks. Fish Res 46:343-357

Carleton JH, Sammarco PW (1987) Effects of substratum irregularity on success of coral settlement: quantification by comparative geomorphological techniques. Bull Mar Sci 40:85-98

* Carré M, Bentaleb I, Bruguier O, Ordinola E, Barrett NT, Fontugne M (2006) Calcification rate influence on trace element concentrations in aragonitic bivalve shells: evidences and mechanisms. Geochim Cosmochim Acta 70 : 4906-4920

Carson HS (2010) Population connectivity of the Olympia oyster in southern California. Limnol Oceanogr 55: 134-148

Carson HS, López-Duarte PC, Rasmussen L, Wang D, Levin LA (2010) Reproductive timing alters population connectivity in marine metapopulations. Curr Biol 20: 1926-1931

* Carson HS, López-Duarte PC, Cook GS, Fodrie FJ, Becker BJ, DiBacco C, Levin LA (2013) Temporal, spatial, and interspecific variation in geochemical signatures within fish otoliths, bivalve larval shells, and crustacean larvae. Mar Ecol Prog Ser 473:133-148

* Cathey AM, Miller NR, Kimmel DG (2012) Microchemistry of juvenile Mercenaria mercenaria shell: implications for modeling larval dispersal. Mar Ecol Prog Ser 465: $155-168$

Charette MA, Sholkovitz ER (2002) Oxidative precipitation of groundwater-derived ferrous iron in the subterranean estuary of a coastal bay. Geophys Res Lett 29:85-1-85-4

Chatry M, Dugas RJ, Easley KA (1983) Optimum salinity regime for oyster production on Louisiana's state seed grounds. Contrib Mar Sci 26:81-94

* Cloern JE, Jassby AD (2012) Drivers of change in estuarinecoastal ecosystems: discoveries from four decades of study in San Francisco Bay. Rev Geophys 50:RG4001

Cook GS, Parnell PE, Levin LA (2014) Population connectivity shifts at high frequency within an open-coast marine protected area network. PLOS ONE 9:e103654

Cordi JA, Meylan MA, Isphording WC (2003) Metal distribution and metal site partitioning, Mobile Bay surface sediments. Trans Gulf Coast Assoc Geol Soc 53:145-159

Dai A, Qian T, Trenberth KE, Milliman JD (2009) Changes in continental freshwater discharge from 1948 to 2004 . J Climate 22:2773-2792

*Dayton PK, Carleton JH, Mackley AG, Sammarco PW (1989) Patterns of settlement, survival and growth of oysters across the Great Barrier Reef. Mar Ecol Prog Ser 54:75-90

*DiBacco C, Levin LA (2000) Development and application of elemental fingerprinting to track the dispersal of marine invertebrate larvae. Limnol Oceanogr 45:871-880

* Dodd JR, Crisp EL (1982) Non-linear variation with salinity of $\mathrm{Sr} / \mathrm{Ca}$ and $\mathrm{Mg} / \mathrm{Ca}$ ratios in water and aragonitic bivalve shells and implications for paleosalinity studies. Palaeogeogr Palaeoclimatol Palaeoecol 38:45-56

* Dong YW, Wang HS, Han GD, Ke CH, Zhan X, Nakano T, Williams GA (2012) The impact of Yangtze River discharge, ocean currents and historical events on the biogeographic pattern of Cellana toreuma along the China coast. PLOS ONE 7:e36178

* Dunphy BJ, Millet MA, Jeffs AG (2011) Elemental signatures in the shells of early juvenile green-lipped mussels (Perna canaliculus) and their potential use for larval tracking. Aquaculture 311:187-192

Fodrie FJ, Becker BJ, Levin LA, Gruenthal K, McMillan PA (2011) Connectivity clues from short-term variability in settlement and geochemical tags of mytilid mussels. J Sea Res 65:141-150 
Gallager SM, Mann R, Sasaki GC (1986) Lipid as an index of growth and viability in three species of bivalve larvae. Aquaculture 56:81-103

* Gancel HN, Carmichael RH, Park K, Krause JW, Rikard S (2019) Field mark-recapture of calcein-stained larval oysters (Crassostrea virginica) in a freshwater-dominated estuary. Estuaries Coasts 42:1558-1569

Génio L, Simon K, Kiel S, Cunha MR (2015) Effects of sample storage and shell orientation on LA-ICPMS trace element measurements on deep-sea mussels. Sci Rep 5:17793

*Gerber LR, Mancha-Cisneros MDM, O'Connor MI, Selig ER (2014) Climate change impacts on connectivity in the ocean: implications for conservation. Ecosphere 5:33

Gillanders BM (2002) Temporal and spatial variability in elemental composition of otoliths: implications for determining stock identity and connectivity of populations. Can J Fish Aquat Sci 59:669-679

Gomes I, Peteiro LG, Albuquerque R, Nolasco R, Dubert J, Swearer SE, Queiroga H (2016) Wandering mussels: using natural tags to identify connectivity patterns among marine protected areas. Mar Ecol Prog Ser 552:159-176

Haase AT, Eggleston DB, Luettich RA, Weaver RJ, Puckett BJ (2012) Estuarine circulation and predicted oyster larval dispersal among a network of reserves. Estuar Coast Shelf Sci 101:33-43

Hayes PF, Menzel RW (1981) The reproductive cycle of early setting Crassostrea virginica (Gmelin) in the northern Gulf of Mexico, and its implications for population recruitment. Biol Bull (Woods Hole) 160:80-88

Hoese HD, Nelson WR, Beckert H (1972) Seasonal and spatial setting of fouling organisms in Mobile Bay and eastern Mississippi Sound, Alabama. Alabama Marine Resources Bulletin No. 8. Alabama Marine Resources Division, Dauphin Island, AL, p 9-17

Isphording WC, Flowers GC (1987) Mobile Bay: the right estuary in the wrong place. In: Lowery TA (ed) Symposium on the Natural Resources of the Mobile Bay Estuary. Alabama Sea Grant Extension Service, Auburn University, Mobile, AL, p 165-174

Jackman S (2008) pscl: political science computational laboratory. R package version 0.95. http://CRAN.R-project. org $/$ package $=$ pscl

Kim CK, Park K (2012) A modeling study of water and salt exchange for a micro-tidal, stratified northern Gulf of Mexico estuary. J Mar Syst 96-97:103-115

Kim CK, Park K, Powers SP, Graham WM, Bayha KM (2010) Oyster larval transport in coastal Alabama: dominance of physical transport over biological behavior in a shallow estuary. J Geophys Res 115:C10019

Kim CK, Park K, Powers SP (2013) Establishing restoration strategy of eastern oyster via a coupled biophysical transport model. Restor Ecol 21:353-362

Kirby MX, Soniat TM, Spero HJ (1998) Stable isotope sclerochronology of Pleistocene and recent oyster shells (Crassostrea virginica). Palaios 13:560-569

Krause-Nehring J, Klügel A, Nehrke G, Brellochs B, Brey T (2011) Impact of sample pretreatment on the measured element concentrations in the bivalve Arctica islandica. Geochem Geophys Geosyst 12:Q07015

Kroll IR, Poray AK, Puckett BJ, Eggleston DB, Fodrie FJ (2016) Environmental effects on elemental signatures in eastern oyster Crassostrea virginica shells: using geo- chemical tagging to assess population connectivity. Mar Ecol Prog Ser 543:173-186

*Kroll IR, Poray AK, Puckett BJ, Eggleston DB, Fodrie FJ (2018) Quantifying estuarine-scale invertebrate larval connectivity: methodological and ecological insights. Limnol Oceanogr 63:1979-1991

* Lazareth CE, Vander Putten E, André L, Dehairs F (2003) High-resolution trace element profiles in shells of the mangrove bivalve Isognomon ephippium: A record of environmental spatio-temporal variations? Estuar Coast Shelf Sci 57:1103-1114

Lee C (1979) Seasonal and spatial study of oyster spat in Mobile Bay and East Mississippi Sound. PhD dissertation, University of South Alabama, Mobile, AL

*Levin LA (2006) Recent progress in understanding larval dispersal: new directions and digressions. Integr Comp Biol 46:282-297

Kevin LA, Huggett D, Myers P, Bridges T, Weaver J (1993) Rare-earth tagging methods for the study of larval dispersal by marine invertebrates. Limnol Oceanogr 38: 346-360

Lorens RB, Bender ML (1980) The impact of solution chemistry on Mytilus edulis calcite and aragonite. Geochim Cosmochim Acta 44:1265-1278

May EB (1971) A survey of the oyster and oyster shell resources of Alabama. Alabama Marine Resources Bulletin No. 4. Alabama Marine Resources Division, Dauphin Island, AL

Medcof JC (1939) Larval life of the oyster (Ostrea virginica) in Bideford River. J Fish Res Board Can 4b:287-301

*Miller SH, Morgan SG, White JW, Green PG (2013a) Interannual variability in an atlas of trace element signatures for determining population connectivity. Mar Ecol Prog Ser 474:179-190

*Miller SH, Morgan SG, White JW, Green PG (2013b) Trace element signatures in larval soft tissues reveal transport, but not population connectivity. Mar Ecol Prog Ser 481:1-10

* Milliman JD, Farnsworth KL, Jones PD, Xu KH, Smith LC (2008) Climatic and anthropogenic factors affecting river discharge to the global ocean, 1951-2000. Global Planet Change 62:187-194

Newell RIE, Kennedy VS, Manuel JL, Meritt D (2005) Behavioral responses of Crassostrea ariakensis and Crassostrea virginica larvae to environmental change under spatially realistic conditions. Final Report to Maryland Department of Natural Resources, Annapolis, MD

Niemand C (2009) The application of elemental fingerprinting techniques to identify population connectivity using Austrovenus stutchburyi recruits. PhD dissertation, The University of Waikato, Hamilton

Norrie CR, Dunphy BJ, Baker JA, Lundquist CJ (2016) Local-scale variation in trace elemental fingerprints of the estuarine bivalve Austrovenus stutchburyi within and between estuaries. Mar Ecol Prog Ser 559:89-102

*North EW, Schlag Z, Hood RR, Li M, Zhong L, Gross T, Kennedy VS (2008) Vertical swimming behavior influences the dispersal of simulated oyster larvae in a coupled particle-tracking and hydrodynamic model of Chesapeake Bay. Mar Ecol Prog Ser 359:99-115

* Park K, Kim CK, Schroeder WW (2007) Temporal variability in summertime bottom hypoxia in shallow areas of Mobile Bay, Alabama. Estuaries Coasts 30:54-65

* Park K, Powers SP, Bosarge GS, Jung HS (2014) Plugging the leak: barrier island restoration following Hurricane 
Katrina enhances habitat quality for oysters in Mobile Bay, Alabama. Mar Environ Res 94:48-55

Patterson HK, Carmichael RH (2018) Dissolved oxygen concentration affects $\delta^{15} \mathrm{~N}$ values in oyster tissues: implications for stable isotope ecology. Ecosphere 9:e02154

Peguero-Icaza M, Sánchez-Velasco L, Lavín MF, Marinone SG, Beier E (2011) Seasonal changes in connectivity routes among larval fish assemblages in a semi-enclosed sea (Gulf of California). J Plankton Res 33:517-533

Pineda J, Hare JA, Sponaugle S (2007) Larval transport and dispersal in the coastal ocean and consequences for population connectivity. Oceanography (Wash DC) 20:22-39

Pollack JB, Kim HC, Morgan EK, Montagna PA (2011) Role of flood disturbance in natural oyster (Crassostrea virginica) population maintenance in an estuary in south Texas, USA. Estuaries Coasts 34:187-197

Powell EN, Klinck JM, Hofmann EE, McManus MA (2003) Influence of water allocation and freshwater inflow on oyster production: a hydrodynamic-oyster population model for Galveston Bay, Texas, USA. Environ Manage 31:100-121

Prytherch HF (1929) Investigation of the physical conditions controlling spawning of oysters and the occurrence, distribution, and settling of oyster larvae in Milford Harbor Connecticut. Fish Bull 44:429-503

* Puckett BJ, Eggleston DB (2016) Metapopulation dynamics guide marine reserve design: importance of connectivity, demographics, and stock enhancement. Ecosphere 7: e01322

Quayle DB, Newkirk GF (1989) Farming bivalve molluscs: methods for study and development. In: Sandifer PA (ed) Advances in world aquaculture, Vol 1. World Aquaculture Society, Baton Rouge, LA, p 1-294

R Core Team (2017) R: a language and environment for statistical computing. R Foundation for Statistical Computing, Vienna

Rikard FS, Walton WC (2010) Use of microalgae concentrations for rearing oyster larvae, Crassostrea virginica. Publication no. MASGP-12-048. NOAA/MississippiAlabama Sea Grant Consortium, Auburn University Shellfish Laboratory, AL

Roever C, Raabe N, Luebke K, Ligges U, Szepannek G, Zentgraf M (2018) klaR: classification and visualization. $\mathrm{R}$ package version 0.6-14. https://cran.r-project.org/ web/packages/klaR/klaR.pdf

Saoud IG, Rouse DB, Wallace RK, Howe J, Page B (2000) Oyster Crassostrea virginica spat settlement as it relates to the restoration of Fish River Reef in Mobile Bay, Alabama. J World Aquacult Soc 31:640-650

Schöne BR (2008) The curse of physiology-challenges and opportunities in the interpretation of geochemical data from mollusk shells. Geo-Mar Lett 28:269-285

Secor DH, Houde ED, Monteleone DM (1995) A markrelease experiment on larval striped bass Morone saxatilis in a Chesapeake Bay tributary. ICES J Mar Sci 52:87-101

Shoji J, Ohta T, Tanaka M (2006) Effects of river flow on larval growth and survival of Japanese seaperch Lateolabrax japonicus (Pisces) in the Chikugo River Estuary, upper Ariake Bay. J Fish Biol 69:1662-1674

Siegel DA, Mitarai S, Costello CJ, Gaines SD, Kendall BE, Warner RR, Winters KB (2008) The stochastic nature of larval connectivity among nearshore marine populations. Proc Natl Acad Sci USA 105:8974-8979
Soniat TM, Klinck JM, Powell EN, Hofmann EE (2012) Understanding the success and failure of oyster populations: periodicities of Perkinsus marinus, and oyster recruitment, mortality, and size. J Shellfish Res 31: 635-646

Sorte CJB, Etter RJ, Spackman R, Boyle EE, Hannigan RE (2013) Elemental fingerprinting of mussel shells to predict population sources and redistribution potential in the Gulf of Maine. PLOS ONE 8:e80868

Stenzel HB (1963) Aragonite and calcite as constituents of adult oyster shells. Science 142:232-233

* Stenzel HB (1964) Oysters: composition of the larval shell. Science 145:155-156

Stout JP, Heck KL Jr, Valentine JF, Dunn SJ, Spitzer PM (1998) Preliminary characterization of habitat loss: Mobile Bay National Estuary Program. Mobile Bay National Estuary Program, Dauphin Island, AL

Strasser CA, Mullineaux LS, Walther BD (2008) Growth rate and age effects on Mya arenaria shell chemistry: implications for biogeochemical studies. J Exp Mar Biol Ecol 355:153-163

* Swearer SE, Forrester GE, Steele MA, Brooks AJ, Lea DW (2003) Spatio-temporal and interspecific variation in otolith trace-elemental fingerprints in a temperate estuarine fish assemblage. Estuar Coast Shelf Sci 56: 1111-1123

*Tamburri MN, Luckenbach MW, Breitburg DL, Bonniwell SM (2008) Settlement of Crassostrea ariakensis larvae: effects of substrate, biofilms, sediment and adult chemical cues. J Shellfish Res 27:601-608

Tatum WM, Van Hoose MS, Havard RW, Clark MC (1995) The 1995 Atlas of major public oyster reefs of Alabama and a review of oyster management efforts 1975-1995. Alabama Marine Resources Bulletin No. 14. Alabama Marine Resources Division, Dauphin Island, AL

* Thébault J, Chauvaud L, L'Helguen S, Clavier J and others (2009) Barium and molybdenum records in bivalve shells: Geochemical proxies for phytoplankton dynamics in coastal environments? Limnol Oceanogr 54: 1002-1014

Thorrold SR, Jones GP, Hellberg ME, Burton RS and others (2002) Quantifying larval retention and connectivity in marine populations with artificial and natural markers. Bull Mar Sci 70:291-308

Thorrold SR, Zacherl DC, Levin LA (2007) Population connectivity and larval dispersal using geochemical signatures in calcified structures. Oceanography (Wash DC) 20:80-89

Vander Putten E, Dehairs F, Keppens E, Baeyens W (2000) High resolution distribution of trace elements in the calcite shell layer of modern Mytilus edulis: environmental and biological controls. Geochim Cosmochim Acta 64: 997-1011

VanderKooy S (ed) (2012) The oyster fishery of the Gulf of Mexico United States: a regional management plan2012 revision. Publication No. 202. Gulf States Marine Fisheries Commission, Ocean Springs, MS

Venables WN, Ripley BD (2002) Modern applied statistics with S, $4^{\text {th }}$ edn. Springer-Verlag, New York, NY

* Vörösmarty CJ, Green P, Salisbury J, Lammers RB (2000) Global water resources: vulnerability from climate change and population growth. Science 289:284-288

*Webb BM, Marr C (2016) Spatial variability of hydrodynamic timescales in a broad and shallow estuary: Mobile Bay, Alabama. J Coast Res 32:1374-1388 
Weiss IM, Tuross N, Addadi L, Weiner S (2002) Mollusc larval shell formation: amorphous calcium carbonate is a precursor phase for aragonite. J Exp Zool 293: 478-491

Wilber DH (1992) Associations between freshwater inflows and oyster productivity in Apalachicola Bay, Florida. Estuar Coast Shelf Sci 35:179-190

Wood S (2012) mgcv: mixed GAM computation vehicle with GCV/AIC/REML smoothness estimation. R package version 1.7-17. https://rdrr.io/cran/mgcv/man/mgcvpackage.html

Editorial responsibility: James McClintock

Birmingham, Alabama, USA

Reviewed by: 2 anonymous referees
Wood LH, Hargis WJ (1971) Transport of bivalve larvae in a tidal estuary. In: Crisp DJ (ed) Fourth marine biology symposium. Cambridge University Press, Cambridge, p 29-44

Zacherl DC (2005) Spatial and temporal variation in statolith and protoconch trace elements as natural tags to track larval dispersal. Mar Ecol Prog Ser 290:145-163

* Zu Ermgassen PS, Spalding MD, Blake B, Coen LD and others (2012) Historical ecology with real numbers: past and present extent and biomass of an imperiled estuarine habitat. Proc R Soc B 279:3393-3400

Submitted: August 21, 2020

Accepted: June 15, 2021

Proofs received from author(s): 28 August, 2021 